\title{
Chemical Characterization of Fine Atmospheric Particles of Water-Soluble Ions and Carbonaceous Species in a Tropical Urban Atmosphere over the Eastern Indo-Gangetic Plain
}

\author{
Babu Priyadharshini ${ }^{1}$, Shubha Verma ${ }^{1 *}$, Abhijit Chatterjee ${ }^{2}$, Sudhir Kumar Sharma ${ }^{3}$, \\ Tuhin Kumar Mandal ${ }^{3}$ \\ ${ }^{1}$ Department of Civil Engineering, Indian Institute of Technology Kharagpur, Kharagpur 721302, India \\ ${ }^{2}$ Environmental Sciences Section, Bose Institute, Kolkata 700054, India \\ ${ }^{3}$ CSIR-National Physical Laboratory, New Delhi 110012, India
}

\begin{abstract}
Ambient fine aerosols and their sources were evaluated in an eastern Indian megacity, Kolkata (KOL), from September 2010 to August 2011. A submicron aerosol sampler (SAS) with two stage stacked filter units (SFU) was devised for simultaneous but discrete collection of water-soluble inorganic ions (WSII) and carbonaceous aerosols (CA; elemental carbon (EC) and organic carbon (OC)). Characteristics of the WSII and CA were identified using ion chromatography and an OC-EC analyzer, respectively, adopting the Interagency Monitoring of PROtected Visual Environments (IMPROVE-A) protocol. The mean annual concentrations of the WSII showed a predominance of cations (anions), consisting of $\mathrm{Ca}^{2+}$, $\mathrm{Mg}^{2+}$, and $\mathrm{Na}^{+}\left(\mathrm{Cl}^{-}, \mathrm{NO}_{3}{ }^{-}\right.$, and $\left.\mathrm{SO}_{4}{ }^{2-}\right)$, with secondary aerosols $\left(\mathrm{NH}_{4}{ }^{+}, \mathrm{NO}_{3}{ }^{-}\right.$, and $\left.\mathrm{SO}_{4}{ }^{2-}\right)$ and $\mathrm{Ca}^{2+}$ each constituting $25 \%$ and $30 \%$, respectively, of the total WSII ( $\mathrm{T}_{\mathrm{WSII}}$ ). The highest mean monthly concentration of $\mathrm{SO}_{4}{ }^{2-}$ and $\mathrm{NO}_{3}{ }^{-}$was observed during the winter month of February and the summer months of March and May, respectively. A pronounced peak in the monthly mean for the non-sea salt- $\mathrm{K}^{+}\left(\mathrm{nss}-\mathrm{K}^{+}\right)$concentration was noticed during October and April, implying the strong influence of biomass burning emissions during these months. Among the sea salt (SS), anthropogenic (AN), and dust (DT) sources of the $\mathrm{T}_{\mathrm{WSII}}$, a predominant contribution from DT in August and from AN in November, April, and May was inferred. The mean annual concentration of OC was three times higher than that of EC, with $43 \%$ of it being secondary OC. Whereas the major sources of OC were inferred to be paved dust, coal combustion, and biomass burning, those of EC were industrial and motor-vehicle non-exhaust emissions, coal combustion, and motor vehicle exhaust.
\end{abstract}

Keywords: Water-soluble inorganic ions; Carbonaceous aerosols; OC-EC ratio; Source apportionment.

\section{INTRODUCTION}

Increasing concentration of anthropogenic aerosols in recent years has been inferred to perturb the earth system exerting detrimental effects on climate, visibility, and human health (IPCC, 2013). A large uncertainty is reported in the radiative forcing exerted due to aerosols (Lee et al., 2016). The chemical composition of aerosols has an important role in determining their relative efficiency to absorb and scatter the solar radiation. Also, the amount of watersoluble aerosol species in the atmosphere would impact the development of cloud condensation nuclei and thereby contribute to the quantity, lifetime, and brightness of

\footnotetext{
* Corresponding author.

Tel.: +91-3222-281794; Fax: +91-3222-255303

E-mail address: shubha@iitkgp.ac.in
}

clouds (Eichel et al., 1996; Lohmann and Feichter, 2005; Rosenfeld et al., 2008). Fine aerosol particles (aerodynamic diameter $\leq 2.5 \mu \mathrm{m}$ ) accumulate in the atmosphere due to the least efficient particle removal mechanisms for them, and hence have a considerably longer atmospheric residence time than coarser or ultrafine aerosol particles (Jaenicke, 1984). These particles thus play a vital role in degrading air quality, reducing visibility, causing adverse health effects and climate change. The chemical composition of fine aerosols, their physical and optical properties, and therefore their interaction with solar radiation and impact on Earth's radiation balance tends to be different from the coarser particles (aerodynamic diameter $\geq 2.5 \mu \mathrm{m}$ ) (Pandolfi et al., 2011; Seinfeld and Pandis, 2012). It is therefore necessary to examine the atmospheric abundance and properties of fine aerosols segregating them from the coarser particles.

In general, the chemical composition of atmospheric aerosols contains water-soluble inorganic species, organic carbon (OC), elemental carbon (EC) and metals (Poschl, 
2005; Squizzato et al., 2016; Jain et al., 2017). Knowledge of aerosol chemical composition can provide essential information about sources and processes that can affect the aerosol concentration at a particular place (Perrino et al., 2009; Zhang et al., 2017). Though the atmospheric abundance of aerosol constituents is known in general, the chemical composition would exhibit temporal and spatial heterogeneity owing to the short residence time of aerosol species, influence from source- and region-specific emission sources and meteorological effects. This heterogeneity therefore leads to uncertainty in the prediction of aerosol-induced climatic impacts, and therefore necessitates examining temporal features of aerosol chemical species, and that distinctly for fine and coarses aerosol particles on a regional to local scale.

In the recent past, campaigns and individual measurements over the Indian mainland provided insights on the chemical composition of aerosols (e.g., over southern India: Hedge et al., 2007; George et al., 2008; Aswini et al., 2018; northern India: Ram et al., 2010a; Rai et al., 2016; Rajput et al., 2018; western India: Rastogi et al., 2014; Gawhane et al., 2017; eastern India: Chatterjee et al., 2012; Das et al., 2015; high altitude location: Chatterjee et al., 2010; Ram et al., 2010; Satsangi et al., 2014). The above measurements were mostly limited to characterization of water-soluble inorganic ions (WSII) or carbonaceous aerosols (CA). There is a lack of information from the available studies on simultaneous analysis of both WSII and carbonaceous aerosols (CA) (discretely sampled for a better characterization) influencing the air mass characteristics over the region.

In the present study, we examine the fine aerosol (aerodynamic diameter $\leq 1.6 \mu \mathrm{m}$ ) chemical constituents of WSII and CA over a tropical urban atmosphere (urb-atm) in the lower Indo-Gangetic Plain (IGP) at Kolkata (KOL) in eastern India during the daytime. Sampling is done using a devised submicron aerosol sampler (SAS) with the two-stage stacked filter units (SFU) for the simultaneous but discrete sampling of WSII and CA. Discrete sampling using separate substrates is done for a better characterization of WSII and CA (Solomon et al., 1989; Berg et al., 1993; Vecchi et al., 2009). The chemical sampling is carried out during daytime hours (10:00-16:00 IST) to evaluate the relative abundance of daytime fine aerosol chemical composition in the urb-atm. The daytime mean aerosol concentration exhibits a low hourly variability and corresponds to the well-mixed layer of atmosphere (Verma et al., 2013; Pani and Verma, 2014). The daytime analysis of aerosol chemical characteristics thus aids in linking the change in the temporal feature (e.g., the trend of monthly mean values) of the measured tracer aerosol species concentration in the atmosphere primarily to the impact of emission sources (Verma et al., 2017). Also, this analysis leads to accounting for aerosol species which would be interacting with the incoming solar radiation and influencing the aerosol optical depth in the eastern Indian urb-atm.

The primary focus of the present study is on the fine aerosol-chemistry through the investigation of the temporal variation of the water-soluble inorganic species, organic and elemental carbonaceous species, along with the partitioning of the aerosols into natural and anthropogenic aerosols. This study also intends to determine the probable sources of aerosol and their monthly variation over a tropical megacity, KOL, where air pollution is already a severe concern. This urb-atm in eastern India (KOL) is also typical as it evinces a strong outflow of aerosol pollutants from the IGP (Kumar and Verma, 2016).

\section{METHODS}

Sampling of ambient fine aerosol particles was carried out over a tropical eastern India urb-atm in the lower IGP, at KOL (Fig. 1(a)). Measurements were carried out at the Indian Institute of Technology (IIT), Kharagpur, Extension Centre $\left(22.57^{\circ} \mathrm{N}, 88.42^{\circ} \mathrm{E}\right)$ situated at the outskirts of Kolkata city, on the rooftop of a building $12 \mathrm{~m}$ above the ground level from September 2010 to August 2011. Kolkata, a metropolitan city, is the third most populous city in India with rapid urbanization and confronts severe pollution (Census of India, 2011, Verma et al., 2013). The Sundarbans delta is located approximately $150 \mathrm{~km}$ to the south of the city. Several industries including those manufacturing chemicals, plywood, rubber products, metals and electrical equipment manufacturing industries are located in and around KOL. The monthly mean of temperature (temp), relative humidity $(\mathrm{RH})$, wind speed (WS), and the rainfall (RF) at the study site is presented in Fig. 1(b). The postmonsoon months of October-December and winter months of January-February are accompanied with a moderately low to the lowest monthly mean of temp, WS, RF and moderately high to the lowest RH. The pre-monsoon months of March to May consist of the highest monthly mean of temp and WS, the lowest to moderately high RF and RH. The southwest monsoon months of June to September consist of the highest monthly mean of temp, $\mathrm{RH}, \mathrm{RF}$ and a moderately high WS. The surface wind direction at the study site as obtained from the wind rose diagram (figure not shown) indicates surface wind being mostly from the north and northwest during post-monsoon months and from the northeast during winter months indicating the influence of air masses mostly from the continental origin. The surface winds during pre-monsoon and monsoon months are found to be mostly from the south and southwest, indicating the influence of marine air mass on aerosols measured in these months. In order to know the possible influence of air mass pathways (e.g., through oceanic or continental regions) on aerosols measured at the study site, seven-day (7-d) back trajectory is calculated using NOAA Hybrid Single-Particle Lagrangian Integrated Trajectory (HYSPLIT) (Draxler and Hess, 1998) for the days of measurement. Back trajectories integrate back in time the path of travel of an air parcel arriving at a receptor location at a given time. The 7-d back trajectory calculations are performed taking into account the residence time of aerosols of the order of a week in the lower atmosphere (Jaenicke, 1981). Further, cluster analysis (Ward, 1963; Sinha et al., 2012; Kumar and Verma, 2016) of back trajectories is done to find out the major pathways (Fig. 1(a)). This analysis led to identifying six pathways of air mass at the 

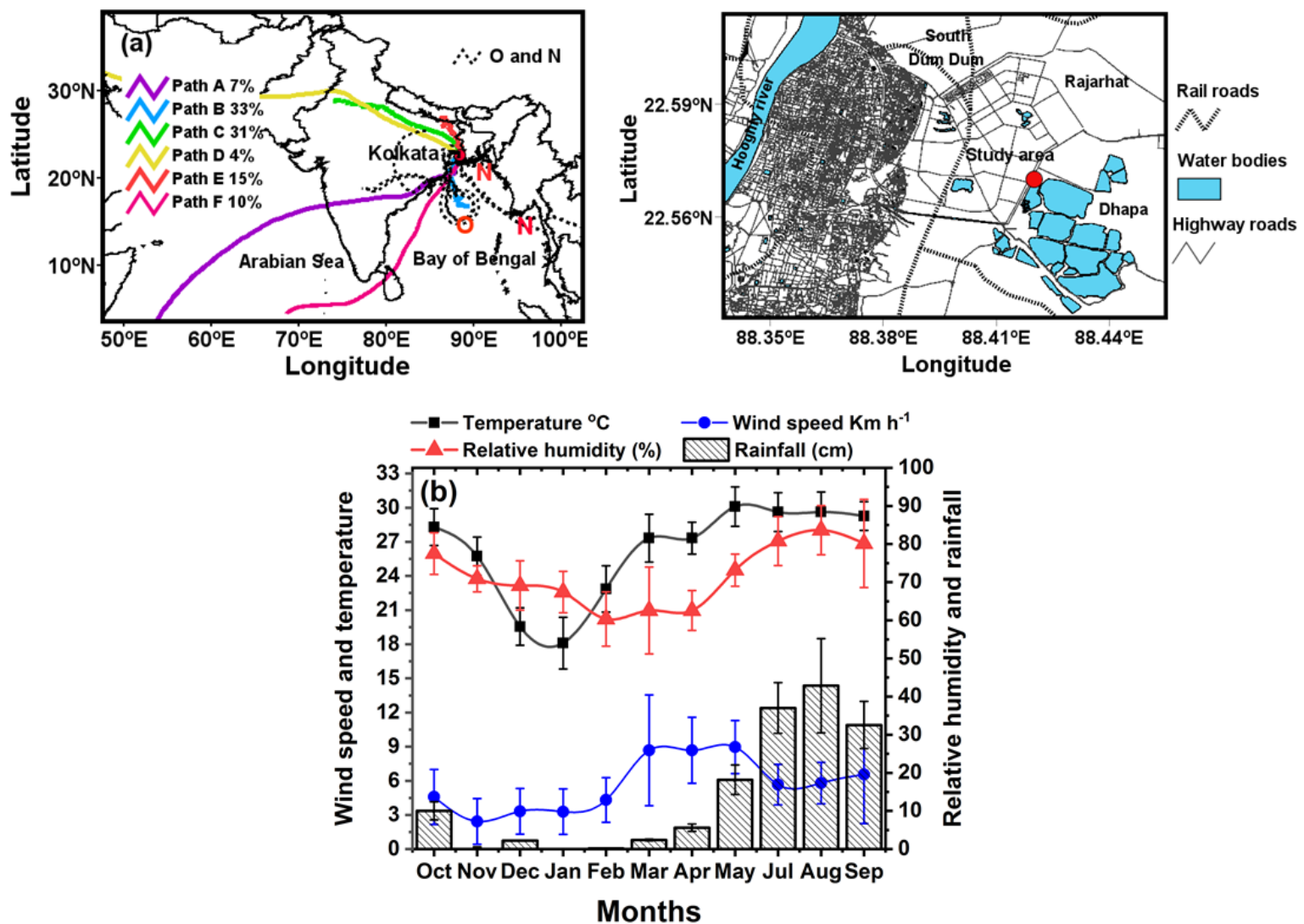

Fig. 1. (a) Location of Kolkata (KOL) on the map of India (left) and study location marked on the map of KOL (right). The colored lines on the map represent clusters showing major air mass pathways to the study site. Dashed black lines represent a few measured days in October $(\mathrm{O})$ and November $(\mathrm{N})$. (b) Temporal trend of monthly mean meteorological parameters such as temperature $\left({ }^{\circ} \mathrm{C}\right)$, relative humidity $(\%)$, wind speed $\left(\mathrm{km} \mathrm{h}^{-1}\right)$ and rainfall $(\mathrm{cm})$ for the study period.

study site, as follows: (i) Path A (IO/AS/SI/ECI), those which originate from Indian Ocean (IO) and traverse over Arabian Sea (AS), South India (SI) and east coast of India (ECI); (ii) Path B (BoB), those which originate and traverse over the Bay of Bengal (BoB); (iii) Path C (IGP), back trajectories which originate in the IGP; (iv) Path D (AFWA/WA/NWI/CNI), those which originate from Africa (AFWA) and pass through west Asia (WA), northwest India (NWI), central India (CNI) and IGP; (v) Path E (NEI), back trajectories originating from northeast India (NEI); (vi) Path F (IO/BoB), those which originate in the $\mathrm{IO}$ and spend relatively longer time over BoB. Analysis of back trajectory clusters indicated a relatively higher frequency of air mass at the study site from Path B and Path C (about $30 \%$ each) than the rest of the paths (4-15\%) (Fig. 1(a)).

\section{Description of Submicron Aerosol Sampler}

An SAS was indigenously designed and fabricated at the workshop of IIT, Kharagpur, using the considerations of Norwegian Institute for Air Research (NILU) protocol (Gabriel et al., 2002; Mayol-Bracero et al., 2002). The framework of SAS consisted of two SFUs in parallel (Fig. 2(a)) with a common inlet of $20 \mathrm{~mm}$ connected to a pick-off tube of $1.8 \mathrm{~cm}$ and a suction pump. The air sucked using a suction pump passes via the common inlet, bifurcates to parallel conduit consisting of four perforated stainless steel filter holders each sandwiched between two polyethylene rings of diameter $34 \mathrm{~mm}$. Nuclepore filter paper $(47 \mathrm{~mm}, 8.0 \mu \mathrm{m})$ was placed on the first stage of both the SFU to collect the coarser fraction (see later). While a quartz filter (Pallflex Tissuquartz 2500 QAT-UP) was placed on the one side, a PTFE membrane filter of pore size $2.0 \mu \mathrm{m}$ was placed on the other side of the SFU's second stage. The quartz filter and PTFE filters were used for the collection of respectively the carbonaceous and WSII species. Discrete sampling using separate substrates is helpful for a better characterization of WSII and CA; e.g., PTFE for WSII (Solomon et al., 1989; Berg et al., 1993; Vecchi et al., 2009) and quartz for CA through thermal carbon analysis (Chow et al., 1993, 2007, 2011). A study examining a simultaneous but discrete measurement of both WSII and CA has been carried out over the Indian oceanic region during the Indian Ocean Experiment (Gabriel et al., 2002; Mayol-Bracero et al., 2002). The quartz filter was pre-fired at $850^{\circ} \mathrm{C}$ for 12 hours before use to remove organic impurities (Mayol-Bracero et al., 2002). Quartz filters are highly durable for thermal methods, which involve high temperatures, desorption. The main advantages of using PTFE filters are these being (i) highly durable, (ii) chemically inert with fewer impurities, (iii) absorbs less moisture and endure a wide range of weather conditions (Vecchi et al., 2009; Chakraborty and Gupta, 2010). 


\section{Operational Details of $S A S$}

The designed SAS with SFU consists of integrated flow meters (CM-flow meter) (Fig. 2(a)). The integrated flow meter measures the flow rate with an accuracy of $\pm 5 \%$ and a precision of 2 to $5 \%$ (http://www.cmflowmeters.in/home/). The flow rate is recorded on both the SFUs at regular intervals of 15-minutes. The flow meter is factory calibrated (http://www.cmflowmeters.in/home/) maintaining an interval of 6 months between the calibrations. The flow meter is calibrated with National Standard to comply with SI traceability, and a calibration certificate is provided by the manufacturer as per National Accreditation Board for Testing and Calibration Laboratories (NABL), New Delhi, India, guidelines.

The SAS was designed to maintain a flow rate of $25 \mathrm{~L} \mathrm{~min}^{-1}$ to achieve a face velocity of $47 \mathrm{~cm} \mathrm{~s}^{-1}$. Resultant face velocity for the given flow rate is calculated using the following formula:

$v=\frac{Q}{A}$

where $v$ is the filter face velocity in $\mathrm{m} \mathrm{s}^{-1} ; Q$ is the volumetric flow rate in $\mathrm{m}^{3} \mathrm{~s}^{-1}$ and $A$ is the filter exposed area in $\mathrm{m}^{2}$ (McDow and Huntzicker, 1990). As mentioned earlier, during operation, a Nuclepore pre-filter (polycarbonate membrane; nominal pore size: $8.0 \mu \mathrm{m}$; Corning Costar) was placed in the first stage of each SFU to collect the coarser aerosol fraction. At the calculated face velocity of $47 \mathrm{~cm} \mathrm{~s}^{-1}$ corresponding to the designed flow rate of $25 \mathrm{~L} \mathrm{~min}^{-1}$ of the devised SAS, the Nuclepore filter would entrap particles of cut-off diameter $1.3 \mu \mathrm{m}$ (refer to Fig. S1, adopted from John et al. (1983). However, during the study period over the tropical urban environment, the average face velocity obtained was $28 \mathrm{~cm} \mathrm{~s}^{-1}$. Also, the devised SAS is designed to transmit particles at $50 \%$ efficiency, with a "cut-off size" of $6.8-9.6 \mu \mathrm{m}$, and at $90 \%$ efficiency, with a cut-off size of 2.6-3.7 $\mu \mathrm{m}$ (Blomquist et al., 2001). Hence, the coarse fraction collected on Nuclepore filter would consist of particles larger than $1.6 \mu \mathrm{m}$ (cut-off size) (calculated for an average face velocity of $28 \mathrm{~cm} \mathrm{~s}^{-1}$ ) and smaller than $10 \mu \mathrm{m}$ (50\% cut-off size of the sampler transmission) aerodynamic diameter. Based on the above, the cut-off size for particle collected on PTFE which is chemically characterized in the present study is $1.6 \mu \mathrm{m}$ (referred as fine particle in the present study). The analysis of WSII species and CA were carried out using ion chromatography (IC) and OC/EC analyzer, respectively (discussed in subsequent sections). The handling of filters (both PTFE and quartz) and their quality assurance were maintained following the considerations of NILU protocol (https://www.nilu.no/projects/ccc/manual/ index.html).

The sample collection was done weekly with at least one sample collected during the middle of each week of a month, amounting to a total of about seventy samples during the period between September 2010 to August 2011. The number of samples used in chemical analysis for the present study were sixty-one. These for each month is as follows: September: 5; October: 5; November: 8; December: 6; January: 5; February: 4; March: 7; April: 6; May: 6; July: 6; August: 3. Aerosol embedded filter papers were stored in containers and refrigerated at $4^{\circ} \mathrm{C}$ until chemical analysis of the respective filters (Chatterjee et al., 2012). The PTFE was subjected to gravimetric analysis to estimate the total mass of aerosol species embedded on the filter. The sum of the chemical determinations consisting of WSII, particulate organic matter (POM), and EC was compared with the mass amount determined on PTFE to estimate the unanalyzed aerosol mass (refer to the section "Characteristics of Organic and Elemental Carbonaceous Aerosol Fractions"). (a)

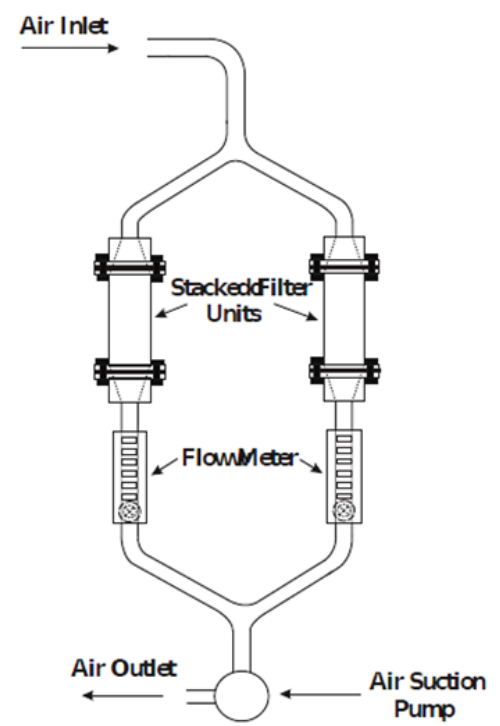

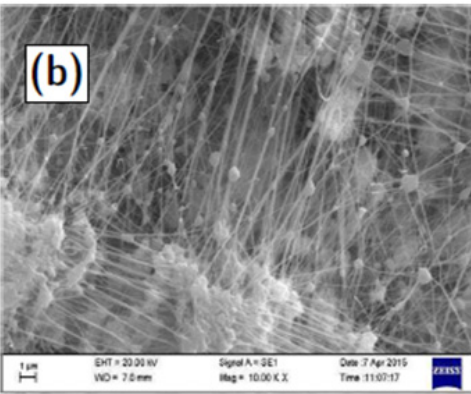
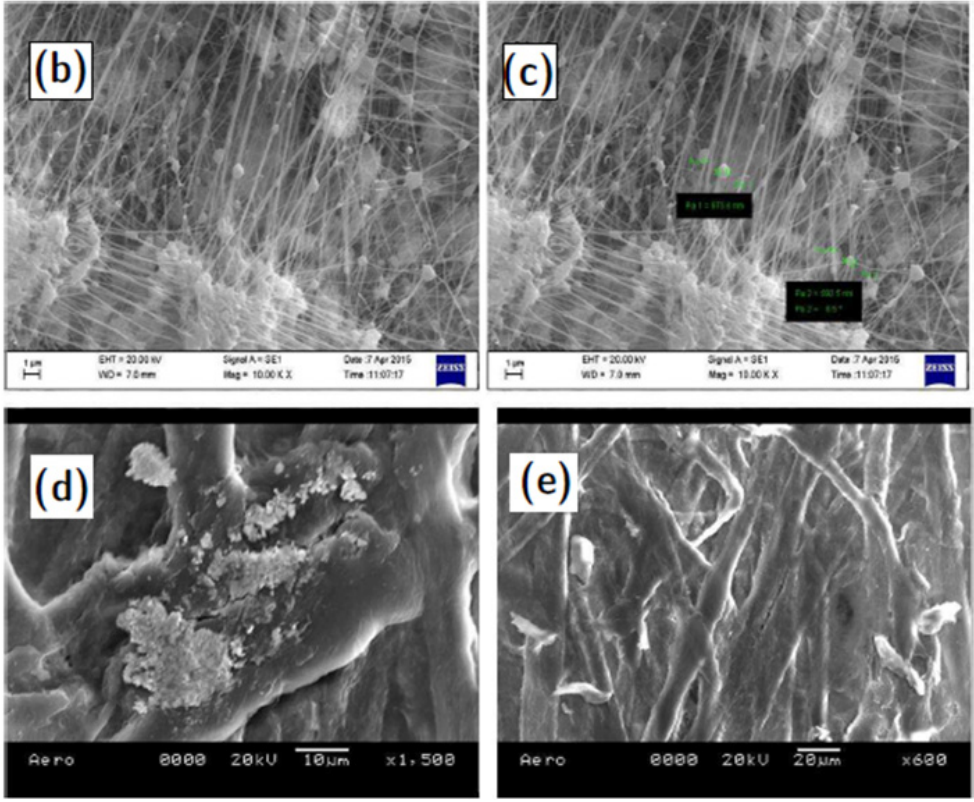

Fig. 2. (a) Submicron aerosol sampler (SAS) with stacked filter unit (SFU). SEM images of (b-c) PTFE filter and (de) Nuclepore filter. 
The present study is mainly focused on evaluating the fine aerosol-chemistry over the eastern Indian urb-atm at KOL using for the first time the devised SAS with SFU. The devised SAS with SFU was used for discrete sampling using separate substrates for a better characterization of WSII and CA. In this study, we aimed to only determine the OC-EC for the sample on quartz filter. We have not carried out the gravimetric analysis of quartz filters or the chemical determination of aerosol species (other than OC-EC) on it.

\section{Determination of Inorganic Ions Using Ion Chromatography}

Fine aerosols impregnated on the PTFE Teflon filter are analyzed chemically for the apportionment of chemical species as described in Gabriel et al. (2002). The watersoluble ionic species collected on PTFE Teflon filters are first wetted with $0.5 \mathrm{ml}$ of methanol, and $39.5 \mathrm{ml}$ Milli-Q water solution (resistivity greater than 18 milliohms), WSII from the filter are extracted into the solution by using ultra-sonicator for 30 minutes of treatment, the necessary time for the complete recovery (78-98\%). The solution containing extracted ions are then analyzed by Metrohm 761 Compact IC for inorganic anions and cations. An electrolyte solution $3.2 \mathrm{mmol} \mathrm{L} \mathrm{ma}_{2} \mathrm{CO}_{3}$ and $1.0 \mathrm{mmol}$ $\mathrm{Na}_{2} \mathrm{HCO}_{3}$ at a flow rate of $0.7 \mathrm{~mL} \mathrm{~min}{ }^{-1}$ was used as an eluent for anion analysis. For the cation analysis, an electrolyte solution of $4 \mathrm{mmol} \mathrm{L}^{-1}$ of tartaric acid and $0.75 \mathrm{mmol} \mathrm{L}^{-1}$ of PDCA (Pyridine-2, 6-dicarboxylic acid)

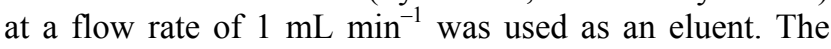
instrumental detection limit of the measured water soluble ionic species is between 0.01 and $0.08 \mu \mathrm{g} \mathrm{m}^{-3}$. An analytical precision between $2 \%$ and $6 \%$ was obtained.

The WSII species measured using IC were as follows: sulfate $\left(\mathrm{SO}_{4}{ }^{2-}\right)$, nitrate $\left(\mathrm{NO}_{3}{ }^{-}\right)$, fluoride $\left(\mathrm{F}^{-}\right)$, chloride $\left(\mathrm{Cl}^{-}\right)$, phosphate $\left(\mathrm{PO}_{4}{ }^{3-}\right)$, potassium $\left(\mathrm{K}^{+}\right)$, sodium $\left(\mathrm{Na}^{+}\right)$, calcium $\left(\mathrm{Ca}^{2+}\right)$, magnesium $\left(\mathrm{Mg}^{2+}\right)$ and ammonium $\left(\mathrm{NH}_{4}^{+}\right)$. The measured $\mathrm{Na}^{+}$is considered as the reference species to estimate the sea-salt fraction (e.g., Granat, 1972). The nonsea salt components of potassium, nss- $\mathrm{K}^{+}$(Hitchcock et al., 1980); sulfate, $\mathrm{nss}_{-} \mathrm{SO}_{4}{ }^{2-}$ (Millero and Sohn, 1992); calcium, nss- $\mathrm{Ca}^{2+}$ (Morales et al., 1998); magnesium, nss$\mathrm{Mg}^{2+}$ (Virkkula et al., 2006); and chloride, nss-Cl- (Holland et al., 1984), are calculated as follows by considering sodium as a reference species (Keene et al., 1986):

$$
\begin{aligned}
& n s s-K^{+}=K_{\text {measured }}^{+}+\mathrm{Na}^{+} \times 0.037 \\
& n s s-\mathrm{SO}_{4}{ }^{2-}=\mathrm{SO}_{4}{ }^{2-} \text { measured }-\mathrm{Na}^{+} \times 0.2516 \\
& n s s-\mathrm{Ca}^{2+}=\mathrm{Ca}^{2+}{ }_{\text {measured }}-\mathrm{Na}^{+} \times 0.0373 \\
& n s s-\mathrm{Mg}^{2+}=\mathrm{Mg}^{2+} \text { measured }-\mathrm{Na}^{+} \times 0.12 \\
& n s s-\mathrm{Cl}^{-}=\mathrm{Cl}_{\text {measured }}^{-}-\mathrm{Na}^{+} \times 1.174
\end{aligned}
$$

Furthermore, we have classified and analyzed the sources of aerosols using individual WSII species such as sea-salt (SS) aerosols $\left(\mathrm{Na}^{+}\right.$, sea-salt components of $\mathrm{Cl}^{-}, \mathrm{Ca}^{2+}, \mathrm{Mg}^{2+}$, $\mathrm{K}^{+}$and $\left.\mathrm{SO}_{4}{ }^{2-}\right)$, anthropogenic (AN) aerosols $\left(\mathrm{NH}_{4}^{+}\right.$, nss-
$\mathrm{K}^{+}, \mathrm{F}^{-}, \mathrm{NO}_{3}{ }^{-}, \mathrm{PO}_{4}{ }^{3-}, \mathrm{nss}_{-} \mathrm{Cl}^{-}$and $\mathrm{nss}-\mathrm{SO}_{4}{ }^{2-}$ ), and dust (DT) aerosols (nss- $\mathrm{Ca}^{2+}$ and nss- $\mathrm{Mg}^{2+}$ ).

\section{Examination of Filters under Scanning Electron Microscope}

Visualization and qualitative analysis of aerosol particles impregnated on the Nuclepore and PTFE filters of SFU were analyzed using ZEISS EVO 60 scanning electron microscope (SEM) equipped with energy dispersive X-ray spectrometer (EDS) at the central research facility (CRF), IIT, Kharagpur. The magnification of SEM varied from about 1000 to 10,000 times with an accelerating voltage of $20 \mathrm{kV}$ and the working distance of $7 \mathrm{~mm}$. This working condition enables to visualize aerosols from a few nanometers to a hundred nanometers. A portion of the Nuclepore and PTFE filter are cut and examined under SEM, and the images obtained are presented in the Figs. 2(b)-2(e). The images of the PTFE filter (Figs. 2(b)-2(c)) show clusters and individual aerosol particles entrapped on the filter, and size analysis reveals the presence of discrete particles less than $1 \mu \mathrm{m}$. Two types of particle shape were mainly distinguished from the SEM analysis of the PTFE filter: (i) spherical and (ii) irregular. As inferred from available studies (e.g., Buseck and Posfai, 1999; Satsangi et al., 2014), the atmospheric particles of natural origin (e.g., soil dust or minerals) have, in general, irregular shapes, and those of anthropogenic origin (e.g., from combustion processes) have a variable morphology. The anthropogenic particles are suggested occurring as individual particle as well as in aggregated form (Satsangi et al., 2014). These particles with spherical shape are inferred being the result of the secondary reactions; irregular particles in the fine range result from coagulation processes (Breed et al., 2002; Satsangi et al., 2014; Li and Shao, 2009). Images of Nuclepore filter paper (Figs. 2(d)-2(e)) evince the presence of larger particles in the range of 2 to $8 \mu \mathrm{m}$. Thus, the presence of fine aerosol particles (mostly submicronic) on the second stage of the filter unit as evinced from the results of SEM analysis, corroborates our inference on cutoff size of particles $(1.6 \mu \mathrm{m})$ as discussed in the section "Operational Details of SAS," and which are chemically characterized in the present study.

\section{Probable Source of Water-soluble Inorganic Ion Species}

The sources of WSII may be natural or anthropogenic; the primary sources of WSII documented from the available information are given as follows. (1) Marine sources: Salts are predominantly formed by sodium and chloride, with a smaller portion made up of sulfate, calcium, magnesium and potassium. Sodium is considered as the main tracer for the particulate matter in marine salt since chlorine gets depleted due to gas phase reactions in atmosphere (White, 2008). Anthropogenic sources of chloride include coal combustion, biomass burning, and waste incineration (Knipping et al., 2003). (2) Crustal sources: The dominant components are aluminum, iron, calcium and potassium, which are generally from crustal origin (Alomary and Belhadj, 2007). Phosphates in the atmosphere are also from the crustal source through incorporation from sedimentary 
rocks through the windblown dust (Guidry and Mackenzie, 2000). The anthropogenic source of $\mathrm{PO}_{4}{ }^{3-}$ is from fertilizers used in agricultural practices. (3) Biomass burning: These emissions mainly consist of carbonaceous compounds and lower concentrations of inorganic components. They contain an inorganic fraction of insoluble ashes and dust and soluble fraction of sulfate, nitrate, potassium and ammonium (Reid et al., 2005). Non-sea salt potassium serves as the potential tracer for biomass burning in the fine range of particles (Andreae, 1983). (4) Anthropogenic aerosols: These aerosols originate in sources such as agricultural activities, industrial and fossil fuel combustion. Aerosol species, such as $\mathrm{NO}_{\mathrm{x}}, \mathrm{SO}_{\mathrm{x}}$, and $\mathrm{NH}_{3}$ formed in the fine range due to primary and secondary formations are from anthropogenic emissions (Malaguti et al., 2015). The main source of $\mathrm{NH}_{3}$ include anthropogenic emissions from gasoline engines, diesel engines, and industrial facilities (Kelly et al., 2013) and it also originates from biomass and agricultural waste burning (Allen et al., 2004; Park and Cho, 2011). It is emitted also from volatilization of animal waste and synthetic fertilizers, losses from soils under native vegetation and agricultural crops, emissions from human excreta (Olivier et al., 1998; Zhang et al., 2008; Aneja et al., 2012, Behera et al., 2013). Nitrate and nsssulfate are widely produced as secondary aerosols during the process of biomass burning, vehicular emissions, and coal combustion (Seinfeld and Pandis, 1998).

\section{Determination of Carbonaceous Aerosols Using IMPROVE-A Protocol}

Carbonaceous aerosol embedded on the quartz filter was analyzed using thermal/optical reflectance (TOR) using the IMPROVE-A in a DRI Model 2001A Thermal/Optical Carbon Analyzer (Desert Research Institute, USA) at CSIR-National Physical Laboratory (CSIR-NPL), New Delhi. OC/EC carbon analyzer works on the principle of preferential oxidation of $\mathrm{OC}$ and $\mathrm{EC}$ at different temperatures, first in the presence of pure helium at four temperatures $\left(140,280,480\right.$ and $\left.580^{\circ} \mathrm{C}\right)$ and second in the presence of $98 \%$ helium and $2 \%$ oxygen at three temperatures (580, 740 and $840^{\circ} \mathrm{C}$ ). In a non-oxidizing helium atmosphere, OC must be volatilized while EC should be combusted in the presence of an oxidizer from the same deposit. The introduction of oxygen into helium atmosphere and evolution of carbon (pyrolyzed OC (OP)) between the process and the return of reflectance to its initial value is defined as the OC/EC split. With the step by step up-gradation of temperature as mentioned above (corresponding to pure helium and helium along with oxygen), eight carbon fractions are released which corresponds to $\mathrm{OC}_{1}, \mathrm{OC}_{2}$, $\mathrm{OC}_{3}, \mathrm{OC}_{4}, \mathrm{EC}_{1}, \mathrm{EC}_{2}, \mathrm{EC}_{3}$ and pyrolyzed carbon fraction OP from different carbon sources (Chow et al., 2004). Abundance of carbon from each of these eight carbon fractions will vary with different sources (Ellis and Novakov, 1982; Cao et al., 2006). Information on eight carbon fractions (OC fractions, EC fractions and OP) have been used in source apportionment (Kim and Hopke, 2004; Cao et al., 2005; Gu et al., 2010; Lee et al., 2016). Based on the characterization of carbon fractions from available studies,
$\mathrm{OC}_{1}$ was found to be abundant in biomass burning and $\mathrm{OC}_{2}$ in coal combustion. $\mathrm{OC}_{3}$ and $\mathrm{OC}_{4}$ are reported to be emitted from paved road dust which is associated with motor vehicle emissions such as brake and tire wear, and oil drips (Ho et al., 2003; Patil et al., 2013). EC $\mathrm{E}_{1}$ was found enriched in industrial and motor-vehicle emissions sample, $\mathrm{EC}_{2}$ and $\mathrm{EC}_{3}$ were chiefly identified from coal combustion and motor vehicle exhaust (Cao et al., 2005).

Furthermore, amount of primary organic carbon (POC) and secondary organic carbon (SOC) are determined in this study using EC tracer method (Castro et al., 1999). The minimum OC/EC value observed during the study period is considered as $\mathrm{OC} / \mathrm{EC}_{\text {min }}$ (i.e., 1.91), and is used for the calculation of SOC in the atmospheric aerosols for the region of interest. Following equations are used for the estimation of POC and SOC:

$[\mathrm{POC}]=\left[\frac{\mathrm{OC}}{\mathrm{EC}_{\text {min }}}\right] \times \mathrm{EC}+c$

$[\mathrm{SOC}]=[\mathrm{OC}]-[\mathrm{POC}] \times \mathrm{EC}$

where POC is primary OC and SOC is secondary OC and $c$ is a parameter to account for noncombustible sources contributing to POC and OC concentration and is assumed negligible in the present study.

The accuracy of DRI carbon analyzer for TOR for Total Carbon (TC), determined by analyzing a known amount of carbon, is 2-6\% (Rau, 1986). Accuracy of the OC/EC split is $5-10 \%$. This accuracy is also influenced by the filter loading and source type. Most of the uncertainty for low concentration samples is from the standard deviation of the field blanks or backup filters. The precision of the instrument for TC, OC, EC and $\mathrm{OC} / \mathrm{EC}$ is $4,6,4$ and $3 \%$, respectively (DRI, 2000). The minimum detection limit (MDL) of the DRI carbon analyzers (based on individual quartz-fiber filters and defined as 3 times the standard deviation $(3 \sigma)$ of their measured results) is obtained as $0.81 \mu \mathrm{g} \mathrm{cm}^{-2}$ for OC and $0.19 \mu \mathrm{g} \mathrm{cm}^{-2}$ for EC (DRI, 2000). The reported concentrations of the measured carbonaceous aerosols (OC and EC) in the present study have been corrected for their respective blank concentrations in the filters. Filter blank values in the present study were 0.31 $\mu \mathrm{g} \mathrm{cm}^{-2}$ for OC and $0.06 \mu \mathrm{g} \mathrm{cm}^{-2}$ for EC, respectively.

\section{RESULTS AND DISCUSSION}

\section{Chemical Composition of Fine Aerosol}

The monthly mean concentrations of the total WSII ( $\mathrm{T}_{\text {WSII }}$ : sum of analyzed WSII species) are shown in Fig. 3(a). The monthly mean of $\mathrm{T}_{\mathrm{WSII}}$ is estimated as $45-$ $86 \mu \mathrm{g} \mathrm{m}^{-3}$ with an annual mean of $65 \pm 13 \mu \mathrm{g} \mathrm{m}^{-3}$. In general, monthly mean of $\mathrm{T}_{\mathrm{WSI}}$ concentrations during October, November, January, and April-May months are found exceeding their respective annual mean value at the study site. These concentrations are twice the lowest mean concentration observed during August. The lowest monthly mean concentration of $\mathrm{T}_{\mathrm{WSII}}$ in the southwest monsoon 
month of August is expected due to wet scavenging of aerosols with the rainfall (Fig. 1(b) High monthly mean value during post-monsoon and winter months is expected due to build-up of atmospheric aerosol load after the monsoon season from anthropogenic activities (refer to "Methods"). The surface wind direction at the study site also indicates the influence of air masses mostly from the continental origin during post-monsoon and winter months. Analysis of back trajectories for the days of measurement also indicates their high frequency to originate in the IGP (Fig. 1(a)). High concentration of aerosols during postmonsoon and winter months is also attributed to a strong emission flux contribution potential from the IGP towards eastern India (Kumar and Verma, 2016). The monthly mean of $\mathrm{T}_{\mathrm{WSII}}$ is also found to be high during pre-monsoon months corresponding to summer season, attributed to an increased influence from biomass burning activities prevalent over the Indian region (Venkataraman et al., 2006; Sahu et al., 2015). Additionally, a high concentration of WSII during summer season is also attributed to an increase in secondary aerosol formation associated with the meteorological conditions of high temperature and $\mathrm{RH}$ prevailing during summer season (Fig. 1(b)). Such meteorological conditions have been inferred being favorable to photochemical oxidation mechanisms (Sharma et al., 2007; Chatterjee et al., 2010, 2012). Analysis of WSII aerosol species is further carried out to get insights into their relative chemical composition distribution and the likely sources influencing atmospheric aerosols.

The monthly mean concentrations and their fractional distribution (\%) of the WSII species are presented in Figs. 3(b)-3(u). It is seen that species such as $\mathrm{Ca}^{2+}, \mathrm{Cl}^{-}$, $\mathrm{Mg}^{2+}, \mathrm{NO}_{3}{ }^{-}, \mathrm{Na}^{+}$and $\mathrm{SO}_{4}{ }^{2-}$ contributes more to $\mathrm{T}_{\mathrm{WSII}}$ than $\mathrm{NH}_{4}^{+}, \mathrm{K}^{+}, \mathrm{PO}_{4}{ }^{3-}$ and $\mathrm{F}^{-}$. Annual mean concentrations of WSII show $\mathrm{Na}^{+}$as one of the abundant species next to $\mathrm{Ca}^{2+}$ and $\mathrm{Mg}^{2+}$. Monthly mean concentration of sodium is specifically higher during months of October, November, January, and April than that of the annual mean (Fig. 3(b)), indicating the increased contribution from marine aerosols in these months. The relative fractional distribution of sodium is as high as $16 \%$ in October. The marine air mass influence to aerosols at KOL is corroborated by analysis of back trajectory (Fig. 1(a)) for the study site, which indicates the pathway of the trajectory over the AS and the BoB, and specifically during days of measurement (dashed black lines in Fig. 1(a) shown for October and November). Also, the surface winds during summer month are found to be mostly from the south and southwest, indicating the influence of marine air-mass on aerosols measured in these months (refer to "Methods").

The annual mean concentration of anions shows $\mathrm{Cl}^{-}$as one of the abundant anions followed by $\mathrm{NO}_{3}{ }^{-}$and $\mathrm{SO}_{4}{ }^{2-}$. The monthly mean concentration of $\mathrm{Cl}^{-}$is seen exhibiting a low variability about the annual mean suggesting the lack of predominating influence of any season specific sources (e.g., biomass burning) of chloride in the urb-atm at KOL. The monthly mean trend of $\mathrm{Cl}^{-}$is found to exhibit a notable dissimilarity with sodium indicating their likely origin from different sources. Calcium (tracer for dust) is higher in concentrations than the other species throughout the study period with nss- $\mathrm{Ca}^{2+}$ accounting for $99 \%$ of the total $\mathrm{Ca}^{2+}$. A peak is spotted in $\mathrm{Ca}^{2+}$ during August, which is twice the monthly mean concentration observed during the other months. A low variability noticed in monthly mean values of calcium concentration during the study period implies the absence of seasonality. The relative fraction of calcium is the highest in August (67\%), compared to $22-34 \%$ in the other months. It is remarkable to note that the monthly mean temporal trend of magnesium is akin with calcium throughout the period except July and August. A good association $\left(\mathrm{R}^{2}=0.72\right)$ of magnesium is marked with calcium, which suggests their source to be similar (i.e., crustal) except during July and August. The pattern of concentration of magnesium during the monsoon month of July and August suggest its source in urb-atm being, besides crustal, likely also from urban and industrial. The monthly mean of the fractional contribution of $\mathrm{Mg}^{2+}$ is the highest during August (26\%) followed by that during July $(17 \%)$ with its contribution being relatively low (10$14 \%$ ) during other months. Annual mean of $\mathrm{nss}-\mathrm{Mg}^{2+}$ accounts for $93 \%$ of the total $\mathrm{Mg}^{2+}$. A higher concentration of calcium and magnesium among analyzed aerosol constituents as found at the study site has also been reported at few other locations over India (e.g., Kanpur and Raipur) (Balakrishna and Pervez, 2009; Srivastava et al., 2009; Chakraborty and Gupta, 2010). Potassium is generally considered to be the biomass burning marker (Andreae, 1983). Prominent peaks of $n s s-\mathrm{K}^{+}$, a biomass burning tracer, is identified during October and April. These peaks corroborate with the information on biomass burning occurrences of crop waste burning and forest biomass as reported in earlier studies (Venkataraman et al., 2006; Sahu et al., 2015). Enhanced concentration of $\mathrm{nss}-\mathrm{K}^{+}$reported in the present study is also consistent with the peak in fire counts obtained from ATSR World Fire Atlas (WFA) (http://due.esrin.esa.int/wfa/) over Indian region. The concentration of nss- $\mathrm{K}^{+}$accounts to $94 \%$ of the total $\mathrm{K}^{+}$, indicating the relative dominance of non-marine sources of $\mathrm{K}^{+}$at Kolkata. Also, a weak correlation is obtained between $\mathrm{Na}^{+}$and $\mathrm{K}^{+}\left(\mathrm{R}^{2}=0.26\right)$ suggesting their primary sources to be different. Concentrations of $\mathrm{F}^{-}$and $\mathrm{PO}_{4}{ }^{3-}$ are relatively low with their maximum observed during November and July. Monthly mean fractional contribution of phosphate $(4-8 \%)$ is higher than fluoride (1-2\%) with high values during November and July. We recall a relatively higher value of $\mathrm{T}_{\mathrm{WSI}}$ during specific months (October, November, January, and April-May as mentioned before) than that during December and February. The WSII species analysis indicates a relatively higher concentration of $\mathrm{Na}^{+}, \mathrm{NH}_{4}^{+}, \mathrm{K}^{+}$, and $\mathrm{PO}_{4}^{-}$during these specific months than that during December and February, attributed to a higher influence of marine and biomass burning sources.

Analysis of secondary WSII aerosols $\left(\mathrm{NH}_{4}^{+}, \mathrm{NO}_{3}^{-}\right.$, and $\mathrm{SO}_{4}{ }^{2-}$ ) indicate the annual mean fractional contribution comprising $25 \%$ of the $\mathrm{T}_{\mathrm{WSII}}$. $\mathrm{NH}_{4}{ }^{+}$is formed by secondary chemical reactions when gaseous $\mathrm{NH}_{3}$ reacts with gaseous $\mathrm{HNO}_{3}$ or $\mathrm{H}_{2} \mathrm{SO}_{4}$ to produce $\mathrm{NH}_{4} \mathrm{NO}_{3}$ or $\left(\mathrm{NH}_{4}\right)_{2} \mathrm{SO}_{4}$ (Appel et al., 1981). Production of $\mathrm{NH}_{4} \mathrm{NO}_{3}$ depends on ammonium 

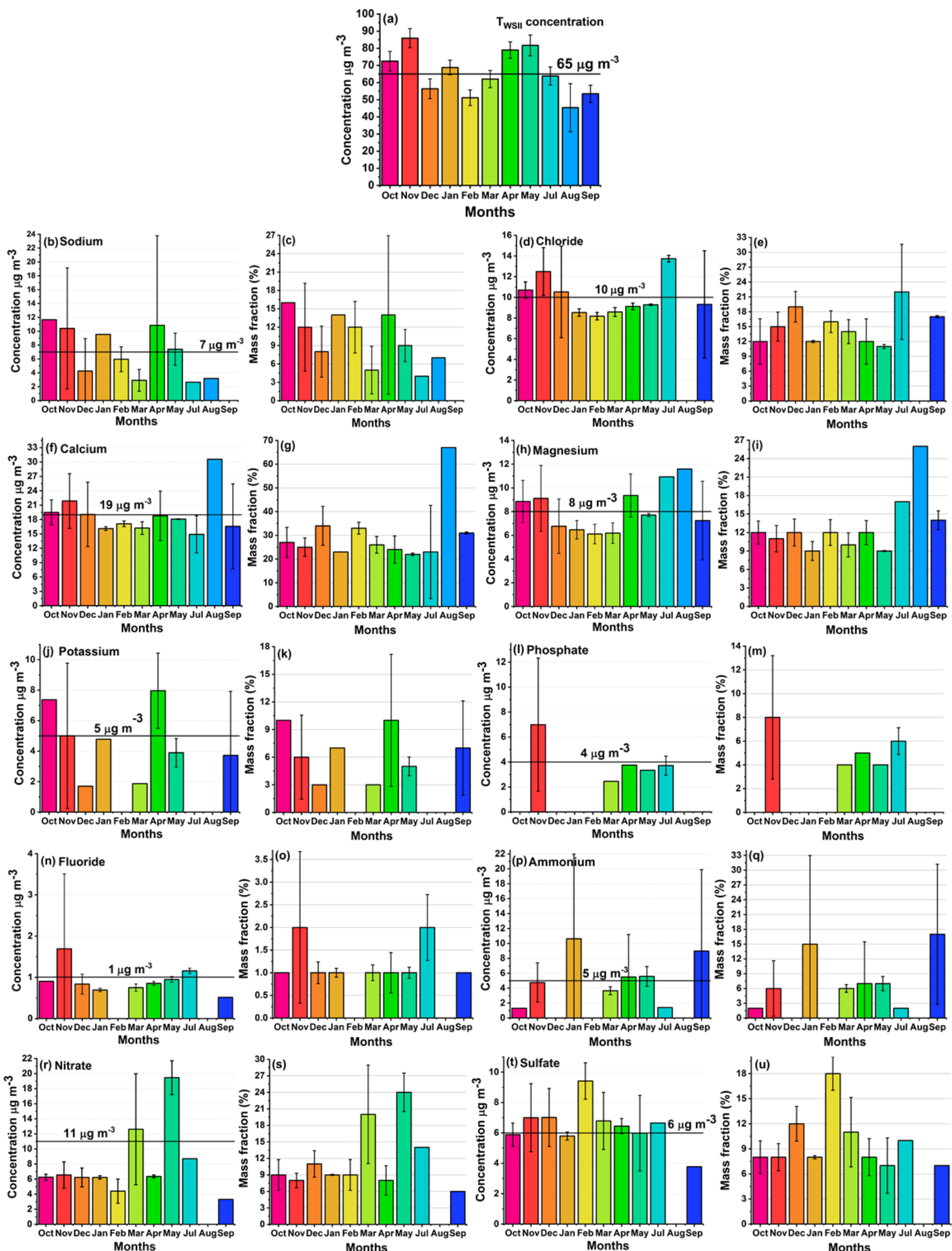

Fig. 3. (a) Monthly mean concentration of $\mathrm{T}_{\mathrm{WSII}}$. (b-u) Monthly mean concentration (Columns 1,3 ) and relative mass fractions (Columns 2, 4) to the respective species concentration of WSII. The relative fraction is estimated as e.g., (Monthly mean conc. of WSII species (i.e., $\left.\mathrm{Na}^{+}\right)$)/(Monthly mean conc. of $\mathrm{T}_{\text {WSII }}\left(\right.$ refer to Fig. 3(a) of $\left.\mathrm{T}_{\text {WSII }}\right)$ ) $\times 100$. The annual mean concentration of individual WSII species is marked as solid black line and its respective value is given in $\mu \mathrm{g} \mathrm{m}^{-3}$. Missing data of some of the aerosol species in the bar-plots is due to their significantly low value (below the instrument detection limit, refer to the section "Determination of Inorganic Ions Using Ion Chromatography") in samples analyzed. 
rich conditions which enhances the formation of $\mathrm{NH}_{4} \mathrm{NO}_{3}$ whereas $\mathrm{NH}_{4}{ }^{+}$-deficit conditions will favor $\left(\mathrm{NH}_{4}\right)_{2} \mathrm{SO}_{4}$. The trend of the monthly mean concentration of $\mathrm{NH}_{4}^{+}$is found to peak during January and September months with the monthly mean values during these months being higher than the annual mean. The peaks observed in $\mathrm{NH}_{4}^{+}$during January and September are attributed to the combined influence of the various sources of $\mathrm{NH}_{4}^{+}$(refer to the section "Probable Source of Water-soluble inorganic ion Species"). It is to be noted that unlike $\mathrm{NH}_{4}^{+}$, the nss- $\mathrm{K}^{+}$, a biomass burning tracer, is observed peaking during October and April, attributed to season specific biomass burning. A molar ratio $\left[\mathrm{NH}_{4}{ }^{+}\right] /\left[\mathrm{SO}_{4}{ }^{2-}\right]$ greater/less than 2 is used to identify the conditions of $\mathrm{NH}_{4}^{+}$as rich/deficit (Alves et al., 2007; Sudheer et al., 2014). Estimated molar ratios show $\mathrm{NH}_{4}{ }^{+}$-rich conditions during January and September and $\mathrm{NH}_{4}^{+}$-deficit condition during other months.

The monthly mean concentration of $\mathrm{SO}_{4}{ }^{2-}$ is found to be the highest (lowest) in February (September) and its fractional contribution to $\mathrm{T}_{\mathrm{WSII}}$ is $7-18 \%$. The annual mean concentration of nss- $\mathrm{SO}_{4}{ }^{2-}$ amounts to $84 \%$ of the total $\mathrm{SO}_{4}{ }^{2-}$. It is interesting to note peak in monthly mean concentration of $\mathrm{NO}_{3}^{-}$during March and May with the observed concentration being 2 times the annual mean concentration. The fractional contribution of $\mathrm{NO}_{3}^{-}$is 6 $24 \%$ with this being the highest during May. While the peak in the monthly mean concentration of $\mathrm{SO}_{4}{ }^{2-}$ is observed during November-February (winter), this of $\mathrm{NO}_{3}{ }^{-}$is during March and May (summer). High $\mathrm{NO}_{3}{ }^{-}$levels in summer could be formed by $\mathrm{OH}^{-}$radical produced by enhanced photochemical reaction favored by high relative humidity with $\mathrm{NO}_{2}$ leading to $\mathrm{HNO}_{3}$ which in turn form particulate $\mathrm{NO}_{3}{ }^{-}$(Hertel et al., 2012). Nevertheless, under hightemperature conditions, the $\mathrm{NO}_{3}^{-}$tends to be volatile, and transforms to $\mathrm{HNO}_{3}$ (Matsumoto and Tanaka, 1996). Thus, the $\mathrm{HNO}_{3}$ formed could react with either calcium carbonate or magnesium chloride to produce particulate calcium nitrate and magnesium nitrate for the evolution of nitrate (Poulain et al., 2011). Nitrate can also exist in the form of $\mathrm{NH}_{4} \mathrm{NO}_{3}$, which is generated by neutralization reaction of $\mathrm{HNO}_{3}$ with $\mathrm{NH}_{3}$ and can occur efficiently only under ammonium rich conditions. However, $\mathrm{NH}_{4} \mathrm{NO}_{3}$ volatilizes under high temperature; hence, the available nitrate manifested during summer in this study might have existed as calcium nitrate and/or magnesium nitrate. It is remarkable to notice the annual mean concentrations of $\mathrm{NO}_{3}{ }^{-}$being slightly higher than $\mathrm{SO}_{4}{ }^{2-}$ at the study site; this result also concurs with that reported at Kanpur (Chakraborty and Gupta, 2010). The mass ratio of $\mathrm{NO}_{3}{ }^{-}$to $\mathrm{SO}_{4}{ }^{2-}$ greater/less than 1 has been used to identify the relative predominating influence of respectively mobile or stationary sources to atmospheric aerosols (Arimoto et al., 1996). The monthly mean ratio of $\mathrm{NO}_{3}{ }^{-}$to $\mathrm{SO}_{4}{ }^{2-}$ is between 0.56 and 4.72 with an annual mean value of $1.6 \pm 1.2$. This ratio is $\geq 1$ during the entire study period except September and February, when it is $\leq 1$. The pattern of this ratio at the study site thus indicates a predominant influence of mobile sources compared to the stationary sources to atmospheric aerosol throughout the study period except during September and February.
It is found that the monthly mean of secondary WSII aerosols ( $\mathrm{SA}$; sum of $\mathrm{NO}_{3}^{-}, \mathrm{SO}_{4}{ }^{2-}$, and $\mathrm{NH}_{4}^{+}$) and primary WSII aerosols (PA; sum of $\mathrm{Na}^{+}, \mathrm{K}^{+}, \mathrm{Ca}^{2+}, \mathrm{Mg}^{2+}, \mathrm{F}^{-}, \mathrm{Cl}^{-}$, and $\mathrm{PO}_{4}^{-}$), are $19-38 \%$ and $62-81 \%$ of the respective monthly mean of TWSII except that for August. The chemical analysis of WSII in August showed the concentration values of SA species and most of PA species (except $\mathrm{Ca}^{2+}$, $\mathrm{Mg}^{2+}, \mathrm{Na}^{+}$) to be notably low (below the instrument detectable limit), possibly due to the washout of atmospheric pollutants. This indicates the presence of dust and SS as prominent aerosol species in the urb-atm at KOL during the monsoon season. The presence of SS is attributed to marine air mass influence (refer to "Methods") due to the onset of monsoon season. The presence of dust during monsoon season is also corroborated by available studies (e.g., Vinoj et al., 2014).

A comparison of the fine WSII at KOL (November to February averaged) in the present study with the measurement at two other urban locations in northern India over the IGP, e.g., Kanpur (KNP; November 11 to January 12) and New Delhi (NDL; November 9 to March 10) is presented in the Table 1 . Among the analyzed WSIIs, the chemical composition shows predominance of $\mathrm{SO}_{4}{ }^{2-}$, and that followed by $\mathrm{Cl}^{-}, \mathrm{NO}_{3}{ }^{-}$, and $\mathrm{NH}_{4}{ }^{+}$at $\mathrm{NDL}$, compared to that of $\mathrm{NO}_{3}{ }^{-}$and followed by $\mathrm{SO}_{4}{ }^{2-}, \mathrm{Ca}^{2+}$, and $\mathrm{NH}_{4}{ }^{+}$at KNP. Unlike at KNP and NDL, there is a predominance of $\mathrm{Ca}^{2+}$ followed by $\mathrm{Cl}^{-}, \mathrm{Na}^{+}$, and $\mathrm{NH}_{4}^{+}$among analyzed WSII at KOL. It is further seen that winter mean concentration of sulfate and nitrate values at NDL and KNP is 2-4 times higher than that at KOL. However, sulfate values are slightly higher than nitrate values at both NDL and KOL but is vice-versa at KNP. A similar feature showing the prevalence of dust as exhibited from chemical analysis in the present study has also been inferred based on AERONET observations at Kolkata (Priyadharshini et al., 2018). These observations also indicated the aerosol type in the eastern Indian urban atmosphere being a mixture of urban/open burning with mixed desert dust. The source of desert dust to the study area is mainly due to long-range transport from the semi-arid regions of India or west Asia (Kumar and Verma, 2016; Priyadharshini et al., 2018).

The mean ionic ratio (the ratio of the sum of anions $\left(\Sigma^{-}\right)$ to the sum of the cations $\left.\left(\sum^{+}\right)\right)$for the entire study period is estimated as 0.83 . It is expected that the missing charges are mainly associated with the possible missing anions in measurements like bicarbonate $\left(\mathrm{HCO}_{3}{ }^{-}\right)$, weak organic acids $\left(\mathrm{HCOO}^{-}, \mathrm{CH}_{3} \mathrm{COO}^{-}, \mathrm{C}_{2} \mathrm{O}_{4}{ }^{2-}\right)$. As mentioned earlier, this study also did not include measurement of insoluble inorganic components (fly ash and mineral dust). A value close to unity (0.7) was also reported by Roy et al. (2016) for a study site at KOL.

\section{Sea Salt, Anthropogenic and Dust Aerosols}

We examine the relative distribution of sea-salt (SS), anthropogenic (AN) and dust (DT) components of WSII at KOL. The monthly mean concentration of SS (sum of $\mathrm{Na}^{+}$, sea-salt components of $\mathrm{Cl}^{-}, \mathrm{Ca}^{2+}, \mathrm{Mg}^{2+}, \mathrm{K}^{+}$and $\mathrm{SO}_{4}{ }^{2-}$ ), AN (sum of $\mathrm{NH}_{4}{ }^{+}, \mathrm{nss}^{+} \mathrm{K}^{+}$, nss- $\mathrm{Cl}^{-}, \mathrm{F}^{-}, \mathrm{NO}_{3}{ }^{-}, \mathrm{PO}_{4}{ }^{3-}$, and nss$\mathrm{SO}_{4}{ }^{2-}$ ), and DT (sum of nss- $\mathrm{Ca}^{2+}$ and nss- $\mathrm{Mg}^{2+}$ ) is shown 


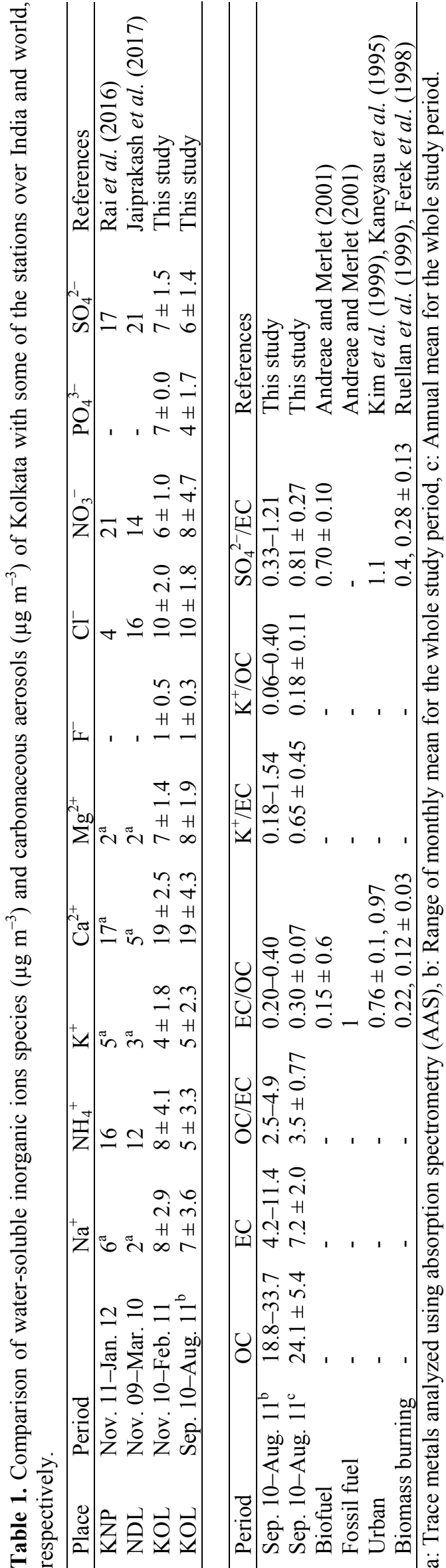

in Fig. 4(a). The relative percent contribution of SS, AN, DT to $T_{\text {WSII }}$ is also presented in Fig. 4(b). The trend of monthly mean concentration of SS exhibits the highest value in October and followed by that in November and January. The back trajectory analysis at surface layers (10, 100 and $500 \mathrm{~m}$ ) indicate the air masses having traversed over the Bay of Bengal before reaching the receptor site (Fig. 1(a), also see dashed lines specifically for sampling days in October-November), thereby corroborating the feature of the monthly mean trend of SS. The trend of monthly mean anthropogenic aerosols concentration is observed having the highest value in the months of November, April, and May. These observed peaks are inferred being associated with the increase in $\mathrm{K}^{+}$and $\mathrm{NO}_{3}^{-}$which therefore leads to a higher anthropogenic aerosol during these months than the other months. The monthly mean of dust concentrations at the study site (excluding for August) do not exhibit notable variation; the dust concentration for August is observed typically higher than other months. The relative percent distributions of monthly mean of SS, AN, and DT is in general observed as 7-35, 26-52, and 30-45\%, except that of August which has exceedingly high concentration of DT. This relative contribution of AN is predominant among analyzed SS, AN, and DT for most of the period except for October, December and February. For the month of October, the relative fractional contribution of SS and DT are equivalent to each other, whereas, for the month of December and February the relative contribution of DT is found predominant. The overall mean for the entire study period indicates equivalent values of AN and DT (about $26 \mu \mathrm{g} \mathrm{m}^{-3}$ each and relative distribution of $40 \%$ each) at the study site over eastern Indian urb-atm.

\section{Characteristics of Organic and Elemental Carbonaceous Aerosol Fractions}

The monthly mean concentration of $\mathrm{OC}$ and EC for the study period is presented in Fig. 5(a). Monthly mean concentration of $\mathrm{OC}$ and EC during the period of study are 19-34 and 4-11 $\mu \mathrm{g} \mathrm{m}^{-3}$ with the annual mean of OC (24 \pm $\left.5 \mu \mathrm{g} \mathrm{m}^{-3}\right)$ being 3 times the EC $\left(7 \pm 2 \mu \mathrm{g} \mathrm{m}^{-3}\right)$. The trend of the monthly mean of OC peaks during September to November. The highest monthly mean of EC is observed during September with the lowest being in April-May. The possible sources of EC-OC during the study period are presented later.

Total estimated aerosol mass (Fig. 5 (b)) analyzed in the present study is calculated by summing the individual species measured (i.e., EC, POM $(\mathrm{OC} \times 1.6)$, and the watersoluble ions) and does not include insoluble inorganic components (fly ash and mineral dust). A conversion factor of 1.6 is used to convert $\mathrm{OC}$ to particulate organic matter (POM) (Chatterjee et al., 2012; Ram et al., 2016). However, this conversion is not precisely known and has been reported ranging from 1.2 to 2.6 (Turpin and Lim, 2001). This uncertainty in the conversion could lead to errors in the determination of OM and, therefore, the total estimated aerosol mass. The monthly mean of total estimated aerosol mass during September to July (excluding August due to absence of OC-EC data) is $97-141 \mu \mathrm{g} \mathrm{m}^{-3}$ with their 

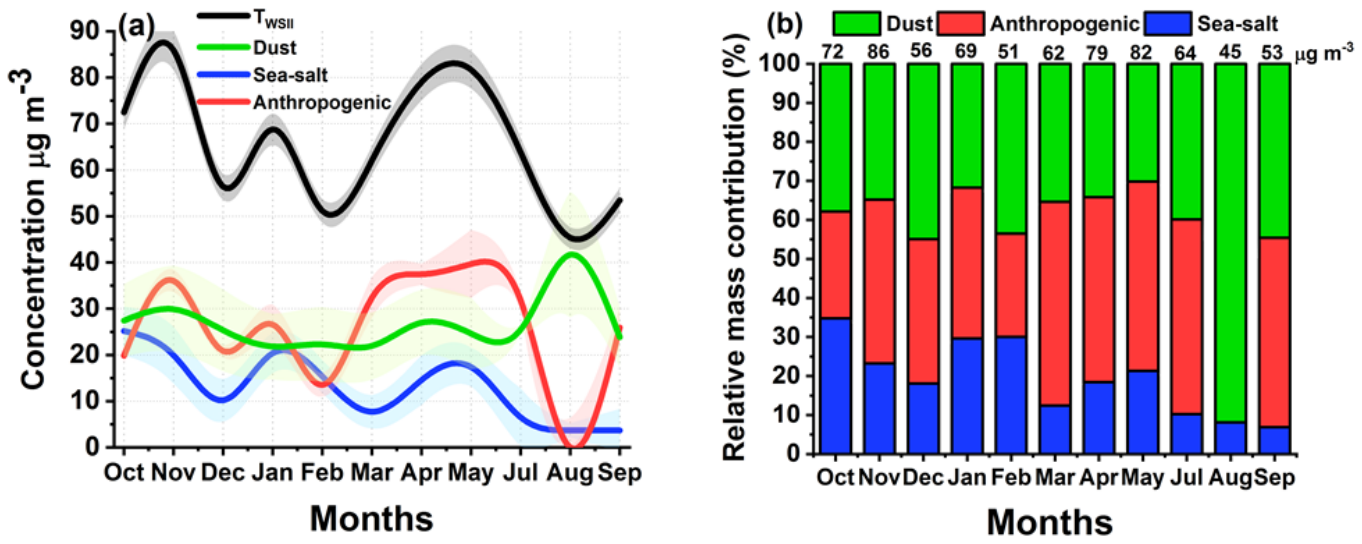

Fig. 4. (a) Temporal trend of monthly mean concentration of SS, AN and DT aerosols along with $\mathrm{T}_{\mathrm{WSII}}$ at KOL. Shaded regions along with line plot indicate the standard deviation. (b) Relative fractional distribution (\%), e.g., (Monthly mean conc. of DT)/Monthly mean conc. of $\mathrm{T}_{\mathrm{WSII}}$ ), of the monthly mean of SS, AN, DT aerosols at KOL.
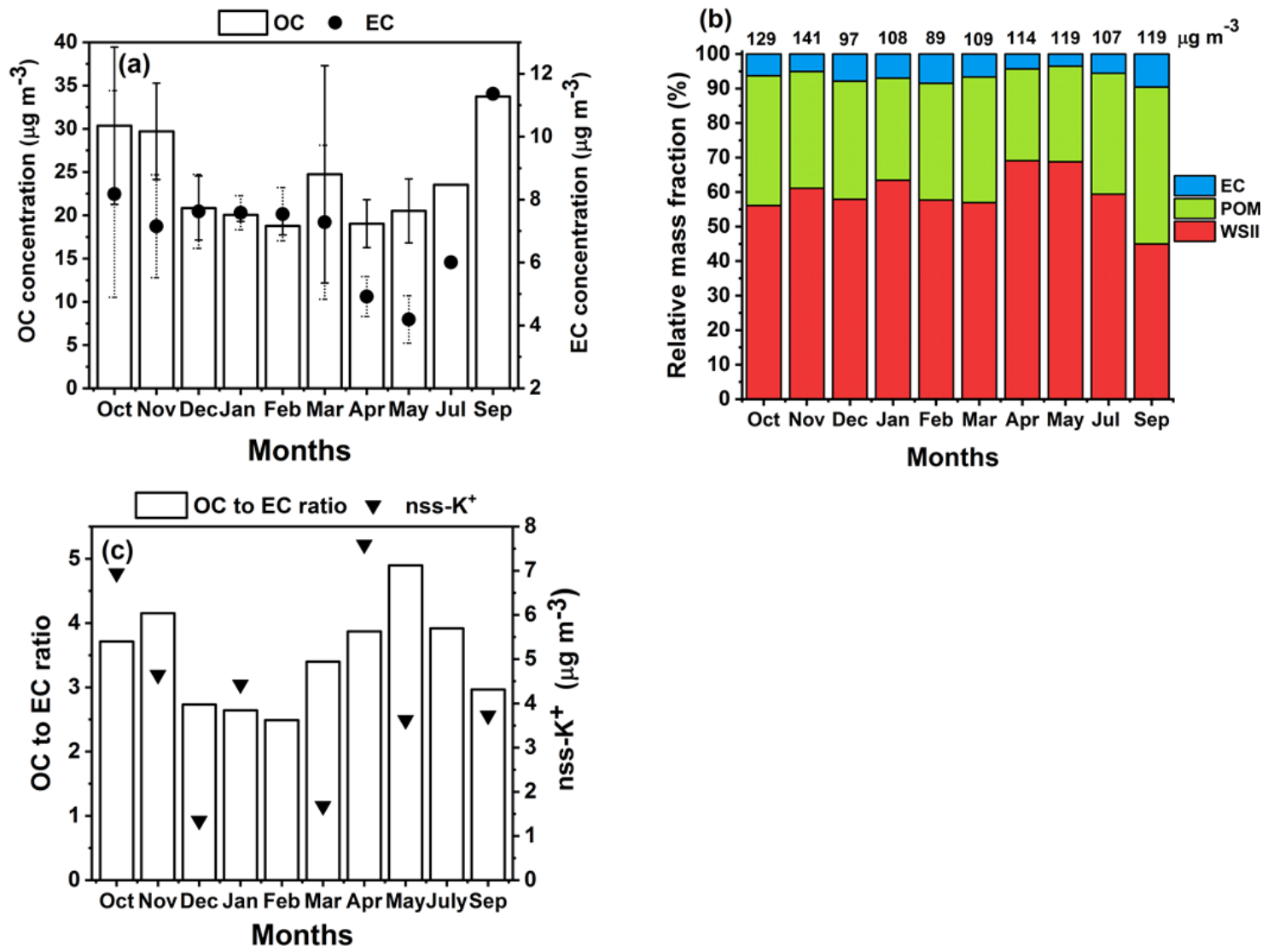

Fig. 5. (a) Trend of monthly mean concentration of OC (denoted in bars) and EC (denoted as circles). (b) The relative fractional distribution of monthly mean of WSII, POM and EC. The monthly mean of total estimated concentration is also shown at the top of each bar. (c) Monthly mean of OC to EC ratio (denoted as bars) and of nss- $\mathrm{K}^{+}$concentration (denoted as inverted triangles).

annual mean being $132 \mu \mathrm{g} \mathrm{m}^{-3}$. Among the analyzed aerosol components (WSII, POM, EC), the relative fraction (Fig. 5(b)) of WSII is the highest throughout, except during September, and is about 2-3 times of POM (27-38\%), with the lowest being that of EC (4-10\%). During the month of September, an increase in POM and EC concentration and a decrease in WSII concentration is noticed, with the relative fraction of POM and WSIIs being equivalent to each other ( $45 \%$ each). The noted feature in the month of September is attributed to the combined impact of biomass burning, coal combustion, and vehicular emissions (based on analysis of OC-EC thermograms; refer to Fig. 6, discussed later), in conjunction with the washout of atmospheric pollutants during the monsoon month. 
Based on the estimated aerosol mass chemically characterized (discussed above) and the total aerosol mass of $\mathrm{PM}_{1.6}$ from the gravimetric analysis of PTFE (48$151 \mu \mathrm{g} \mathrm{m}^{-3}$ ), the unanalyzed fraction is estimated. The unanalyzed fraction during the period of study is estimated as $5-25 \%$ with a higher value for September-October (10$15 \%)$ and the highest for December $(25 \%)$. The unanalyzed fraction is attributed to unanalyzed insoluble inorganic components (fly ash and mineral dust). This fraction may also be due to PM-bound and PM-adsorbed water on PTFE (Perrino et al., 2013).

The estimated monthly mean of SOC (POC) values using EC tracer method (refer to the Section "Determination of Carbonaceous Aerosols Using IMPROVE-A Protocol") is about $23-61 \%(39-77 \%)$ of the respective monthly mean of total OC. The annual mean of these value is $43 \%$ $(57 \%)$ of that of total OC. While the highest value for SOC is observed during the month of May and the lowest during February, it is vice-versa for POC. The highest SOC production during May is attributed to the prevalent meteorological conditions. A relatively high value of temperature and relative humidity during May (Fig. 1(b)) is inferred being favorable to enhance the photochemical process (Chatterjee et al., 2012). In contrast of that during May, a relatively low temperature and relative humidity during February (Fig. 1(b)) might have led to the lower production of SOC.

The ratio of OC to EC is further analyzed (Fig. 5(c)) to qualitatively evaluate the potential emission sources and the possible mechanism of SOC formation through gas-toparticle conversion. The monthly mean of nss- $\mathrm{K}^{+}$is also presented in Fig. 5(c). The calculated monthly mean of OC to EC ratio during the study period is $2-5$ with an annual mean value of 3 (also mentioned before). A ratio higher than 2 is inferred as being the presence of secondary organic aerosols (Chow et al., 1996). Peak in this ratio is observed during October-November and then during March-July. The trend of the monthly mean of nss- $\mathrm{K}^{+}$indicates the highest peak during October and April with moderate peak during November, January, May, and September. The peaked values of OC-EC ratio is concordant to nss- $\mathrm{K}^{+}$ during most of the period, thereby indicating a predominant influence of biomass combustion sources to OC measured in eastern Indian urb-atm. A previous study conducted over a residential-cum-commercial site in Kolkata during 2006 by Chatterjee et al. (2012) reported annual mean concentrations of $\mathrm{OC}, \mathrm{EC}$, and $\mathrm{OC}$ to $\mathrm{EC}$ ratio as $12 \pm 6,6$ \pm 3 and $2.0 \pm 0.4 \mu \mathrm{g} \mathrm{m}^{-3}$. Comparison of the present study with Chatterjee et al. (2012) indicates an increase of 2 times in OC and 1.5 times in OC to EC ratio with only a slight increase in EC for the present study.

Studies conducted on carbonaceous aerosols over the last decade on different temporal scales (monthly/annual mean) in various regions of India reported OC to EC ratio in the range of 2-8.4 (Venkataraman et al., 2002; Rengarajan et al., 2007; Ram et al., 2008; Rastogi and Sarin, 2009; Ram and Sarin, 2010; Ram et al., 2012; Tiwari et al., 2013; Safai et al., 2014; Panda et al., 2016; Singh et al., 2016). A ratio of 6-8 is reported over northwestern India (viz., Ahmedabad, Mount Abu) and northern India (viz., Allahabad, Hisar) whereas a ratio less than 3 (Mumbai) is detected over western India and eastern India (viz., Bhubaneswar). Annual mean of the ratio of OC to EC obtained in the present study is 1.5 to 2 times higher than the ratios reported in Chatterjee et al. (2012) and Panda et al. (2016) over eastern India while this ratio is 2 times lower than the ratio reported over northern, northwestern and western India (Rengarajan et al., 2007; Ram et al., 2008; Rastogi and Sarin, 2009; Ram and Sarin, 2010; Tiwari et al., 2013; Safai et al., 2014, Pipal et al., 2016). Inferences referred from the above studies showing a high OC to EC ratio is attributed to the predominance of biomass burning over the specific regions (Rengarajan et al., 2007; Ram et al., 2008; Rastogi and Sarin, 2009; Ram and Sarin, 2010; Rastogi et al., 2015).

We also analyze the ratio of the aerosol species, i.e., $\mathrm{EC} / \mathrm{OC}, \mathrm{nss}^{-} \mathrm{K}^{+} / \mathrm{EC}, \mathrm{SO}_{4}{ }^{2-} / \mathrm{EC}$, in order to qualitatively know the possible emission sources to measured aerosols. The value of these ratios is shown in the Table 1 . These ratios are shown as a range of the monthly mean for the entire period of study. The value of these ratios used in available studies to suggest the possible impact of emission sources is also shown in Table 1. The ratio EC/OC from the present study is in general found to be low $(<0.4)$ throughout the study period and indicates the predominant signature of biomass burning sources influencing the atmospheric aerosols. The high value of ratio $\mathrm{K}^{+} / \mathrm{EC}$ (i.e., $>0.2$ ) also indicates the similar signature as the above. However, the ratio $\mathrm{SO}_{4}{ }^{2-} / \mathrm{EC}$, which is near to 1 throughout the study period, indicates signature of urban influence. The chemical characterization of fine aerosol particles suggests the signatures of mixed influence of urban, open burning, and dust impacting atmospheric aerosols over eastern Indian urban atmosphere. A mixed influence of emission sources to ambient aerosols over eastern Indian urban atmosphere has also been suggested in a recent study based on a hybrid source-receptor analysis through application of fuzzy $c$-means clustering to back-trajectory data combined with emission flux and residence time weighted aerosols analysis (Kumar and Verma, 2016). The quantitative evaluation of the impact of emission sources to aerosol species needs to be further done through simulating emissions in a chemical transport model in conjunction with that through Positive Matrix Factorization (PMF) applied to the measured concentration.

The OC and EC fractions (refer to "Determination of Carbonaceous Aerosols Using IMPROVE-A Protocol") obtained from thermograms of OC-EC are presented respectively in Figs. 6(a)-(d) and Figs. 6(e)-6(g). The monthly mean of $\mathrm{OC}_{1}$ is observed peaking during months of March to September, also concordant with the peaks in nss- $\mathrm{K}^{+}$and $\mathrm{OC}$ to $\mathrm{EC}$ ratio (Fig. 5(c)) (discussed previously) thereby manifesting the influence of biomass burning during these months. The monthly mean of $\mathrm{OC}_{2}$ is found high during the months of April to May followed by July to September and October to November, indicative of possibly enhanced contribution to OC from coal combustion activities in industrial sector. The concentration of components $\mathrm{OC}_{3}$ 

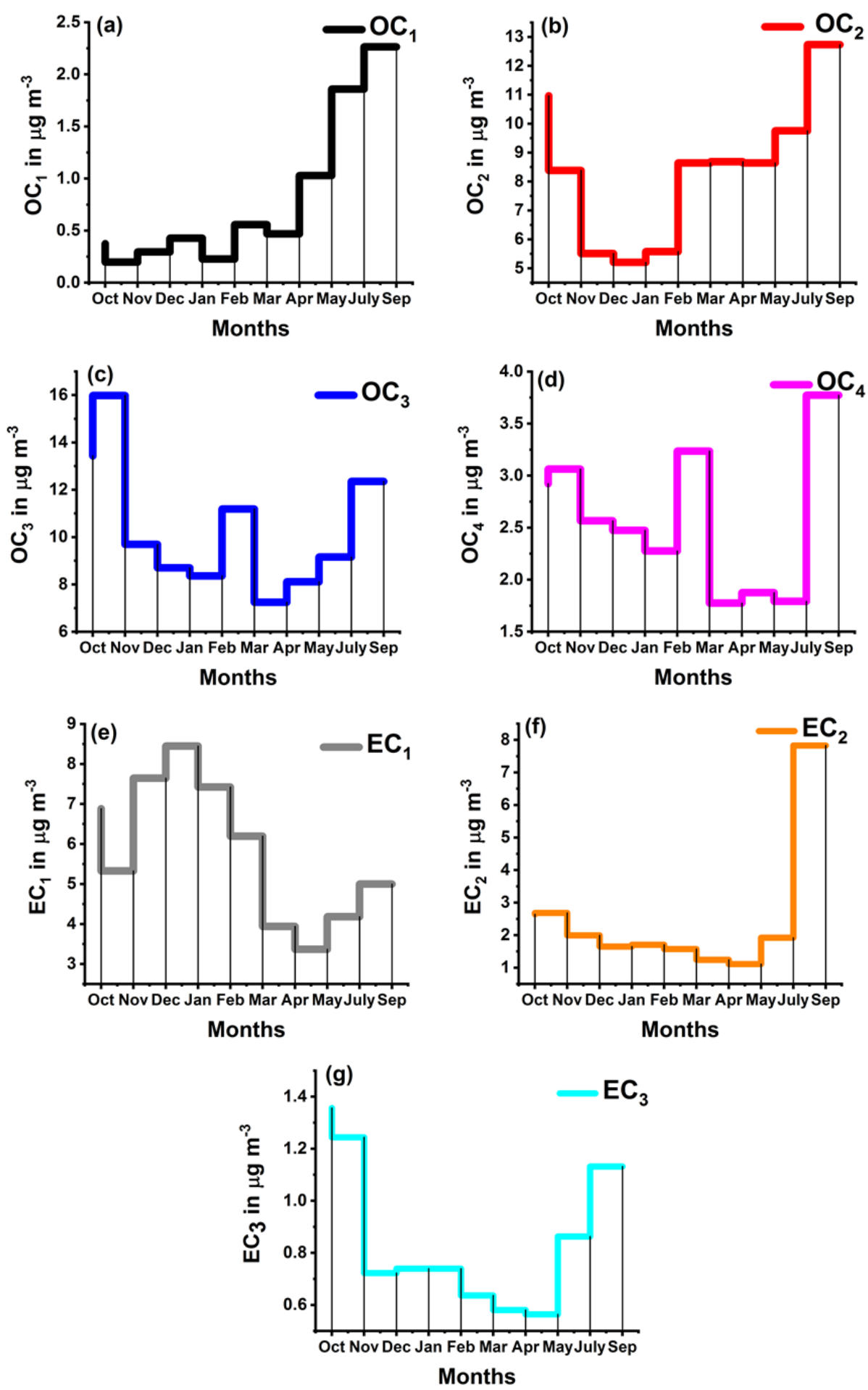

Fig. 6. Temporal trend of monthly mean concentration of thermally derived $\mathrm{OC}$ fractions and $\mathrm{EC}$ fractions. (a-d) $\mathrm{OC}_{1-}$ $\mathrm{OC}_{4} .(\mathrm{e}-\mathrm{g}) \mathrm{EC}_{1}-\mathrm{EC}_{3}$.

and $\mathrm{OC}_{4}$ is observed to be high during months of October, November, February, March, July, and September, indicative of possibly enhanced contribution to OC from paved dust associated with motor vehicle emissions. Analysis of the relative contribution (\%) of annual mean of $\mathrm{OC}$ fractions (i.e., $\mathrm{OC}_{1}, \mathrm{OC}_{2}, \mathrm{OC}_{3}, \mathrm{OC}_{4}$ ) to that of the total carbon (TC) indicates a larger fractional contribution from
$\mathrm{OC}_{3}$ and $\mathrm{OC}_{4}(41 \%)$ than that from $\mathrm{OC}_{2}(27 \%)$ and $\mathrm{OC}_{1}$ $(2 \%)$. This analysis, therefore, indicates the predominant influence of re-suspended paved dust followed by coal combustion and biomass burning sources at the study site.

Amongst the three $\mathrm{EC}$ components $\left(\mathrm{EC}_{1}, \mathrm{EC}_{2}, \mathrm{EC}_{3}\right)$, the monthly mean of $\mathrm{EC}_{1}$ (indicative of influence from industrial and motor-vehicle emissions) is typically high 
during months of October to March; of $\mathrm{EC}_{2}$ (indicative of influence from coal combustion), during September with a low variability in other months; of $\mathrm{EC}_{3}$ (indicative of influence from motor vehicle exhaust), during months of October, November, July, and September. The relative contribution (\%) of annual mean of $\mathrm{EC}$ fractions (i.e., $\mathrm{EC}_{1}$, $\mathrm{EC}_{2}$ and $\left.\mathrm{EC}_{3}\right)$ to that of the TC is as follows: $\mathrm{EC}_{1}(19 \%)$, $\mathrm{EC}_{2}(8 \%)$ and $\mathrm{EC}_{3}(3 \%)$. The relative fractional contribution of components of $\mathrm{EC}$ to $\mathrm{TC}$ reveals the predominance of EC component from industrial and motor vehicle emissions followed by coal combustion and motor vehicle exhaust at the study site.

\section{CONCLUSIONS}

In the present study, fine particulate matter $(\leq 1.6 \mu \mathrm{m})$ in a tropical urban atmosphere (above Kolkata (KOL), on the lower Indo-Gangetic Plain in eastern India) was sampled during the daytime and chemically characterized to evaluate the relative abundance, temporal variation, and probable sources of the ambient aerosol species. A submicron aerosol particle sampler (SAS) with double two stage stacked filter units (SFU) was devised for a simultaneous but discrete collection of water-soluble inorganic ions (WSII) and carbonaceous aerosols (CA; elemental carbon (EC) and organic carbon (OC)).

The most abundant WSII species throughout the period of study were $\mathrm{Ca}^{2+}, \mathrm{Mg}^{2+}$, and $\mathrm{Na}^{+}$among the cations and $\mathrm{Cl}^{-}, \mathrm{NO}_{3}{ }^{-}$, and $\mathrm{SO}_{4}{ }^{2-}$ among the anions. The mean monthly concentrations of these cations and anions constituted 41$57 \%$ and $28-46 \%$, respectively, of the total WSII ( $\mathrm{T}_{\mathrm{WSII}}$ ). The secondary WSII aerosols $\left(\mathrm{NH}_{4}^{+}, \mathrm{NO}_{3}^{-}\right.$, and $\left.\mathrm{SO}_{4}{ }^{2-}\right)$ contributed $25 \%$ of the $\mathrm{T}_{\mathrm{WSII}}$, which was almost equal to the portion from $\mathrm{Ca}^{2+}(30 \%)$.

Whereas the mean monthly concentration of $\mathrm{SO}_{4}{ }^{2-}$ peaked during winter (February), that of $\mathrm{NO}_{3}{ }^{-}$peaked during summer (March and May). The concentration of $\mathrm{NO}_{3}^{-}$was 2-3 times higher than that of $\mathrm{SO}_{4}{ }^{2-}$ in summer, unlike during the other months, when the concentrations were nearly identical.

The trend of the monthly mean of nss- $\mathrm{K}^{+}$exhibited pronounced peaks in October and April, suggesting the predominant influence of biomass burning emissions at the study site during these months.

Of the sea-salt (SS), anthropogenic (AN), and dust (DT) components of the $\mathrm{T}_{\mathrm{WSII}}$, DT was predominant during August, AN during November, April, and May, and SS during October, November, and January. The fractional contribution of AN was predominant among these three components for most of the study period.

The mean monthly concentration of OC exhibited a larger variability than that of EC, and the mean annual concentration of the former- $43 \%$ of which was formed by secondary $\mathrm{OC}$ - was 3 times that of the latter. The monthly mean of the $\mathrm{OC}$ to EC ratio displayed temporal peaks concurrent with those of nss- $\mathrm{K}^{+}$. The contribution to the monthly mean (September-July) from the WSII, POM, and EC was $45-69 \%, 27-45 \%$, and $4-10 \%$, respectively, of the total estimated aerosol mass concentration of these components. WSIIs' contribution peaked during April and May, whereas POM and EC's contributions peaked during September. The information derived from our measurements indicated high $\mathrm{SO}_{4}{ }^{2-} / \mathrm{EC}$ and $\mathrm{nss}-\mathrm{K}^{+} / \mathrm{EC}$ ratios in conjunction with low $\mathrm{EC} / \mathrm{OC}$ ratios throughout the experimental period at the study site. Based on the analysis of the OC-EC thermograms, the main source of $\mathrm{OC}$ was probably paved road dust, followed by coal combustion and biomass burning, whereas the main sources of EC were probably industrial and non-exhaust motor vehicle emissions, followed by coal combustion and motor vehicle exhaust.

The chemical profile of these fine aerosol particles suggests the mixed influence of urban, open burning, and dust aerosols in the urban atmosphere of eastern India. Further analysis via positive matrix factorization (PMF) to quantify the sources affecting the chemical composition of this atmosphere (above Kolkata) is in progress and will be presented in a future study. The current study provides information on the relative abundance of fine aerosol species, which are responsible for the extinction of incoming solar radiation and an increase in aerosol optical depth. This data will be used in an aerosol optical property and radiative transfer model to estimate species-specific effects in the eastern Indian urban atmosphere.

\section{ACKNOWLEDGMENTS}

Computing resources and experimental work at the Indian Institute of Technology, Kharagpur, were supported through a grant received from the Department of Science and Technology, Govt. of India (SR/FTP/ES-54/2007). B. Priyadharshini acknowledges her financial support from the Indian Ministry for Human Resource Development.

\section{SUPPLEMENTARY MATERIAL}

Supplementary data associated with this article can be found in the online version at http://www.aaqr.org.

\section{REFERENCES}

Allen, A., Cardoso, A.A. and Da Rocha, G. (2004). Influence of sugar cane burning on aerosol soluble ion composition in Southeastern Brazil. Atmos. Environ. 38: 5025-5038.

Alomary, A.A. and Belhadj, S. (2007). Determination of heavy metals $(\mathrm{Cd}, \mathrm{Cr}, \mathrm{Cu}, \mathrm{Fe}, \mathrm{Ni}, \mathrm{Pb}, \mathrm{Zn})$ by ICP-OES and their speciation in Algerian Mediterranean Sea sediments after a five-stage sequential extraction procedure. Environ. Monit. Assess. 135: 265-280.

Alves, C., Pio, C., Campos, E. and Barbedo, P. (2007). Size distribution of atmospheric particulate ionic species at a coastal site in Portugal. Quim. Nova 30: 1938-1944.

Andreae, M.O. (1983). Soot carbon and excess fine potassium: Long-range transport of combustion-derived aerosols. Science 220: 1148-1151.

Andreae, M.O. and Merlet, P. (2001). Emission of trace gases and aerosols from biomass burning. Global Biogeochem. Cycles 15: 955-966. 
Aneja V.P., Schlesinger, W., Erisman, J.W., Behera, S.N., Sharma, M. and Battye, W. (2012). Reactive nitrogen emissions from crop and livestock farming in India. Atmos. Environ. 47: 92-103.

Appel, B., Tokiwa, Y. and Haik, M. (1981). Sampling of nitrates in ambient air. Atmos. Environ. 15: 283-289.

Arimoto, R., Duce, R.A., Savoie, D.L., Prospero, J.M., Talbot, R., Cullen, J.D., Tomza, U., Lewis, N.F. and Ray, B.J. (1996). Relationships among aerosol constituents from Asia and the North Pacific during PEM-West. $J$. Geophys. Res. 101: 2011-2023.

Aswini, A.R., Hegde, P. and Nair, P.R. (2018). Carbonaceous and inorganic aerosols over a sub-urban site in peninsular India: Temporal variability and source characteristics. Atmos. Res. 199: 40-53.

Balakrishna, G. and Pervez, S. (2009). Source apportionment of atmospheric dust fallout in an urban-industrial environment in India. Aerosol Air Qual. Res. 9: 359367.

Behera, S.N., Sharma, M., Aneja, V.P. and Balasubramanian, R. (2013). Ammonia in the atmosphere: A review on emission sources, atmospheric chemistry and deposition on terrestrial bodies. Environ Sci. Pollut. Res. 20: 8092-8131.

Berg, T., Røyset, O. and Steinnes, E. (1993). Blank values of trace elements in aerosol filters determined by ICPMS. Atmos. Environ. 27: 2435-2439.

Blomquist, B.W., Huebert, B.J., Howell, S.G., Litchy, M.R., Twohy, C.H., Schanot, A., Baumgardner, D., Lafleur, B., Seebaugh, R. and Laucks, M.L. (2001). An evaluation of the community aerosol inlet for the NCAR C-130 research aircraft. J. Atmos. Oceanic Technol. 18: 1387-1397.

Breed, C., Arocena, J. and Sutherland, D. (2002). Possible sources of $\mathrm{PM}_{10}$ in Prince George (Canada) as revealed by morphology and in situ chemical composition of particulate. Atmos. Environ. 36: 1721-1731.

Buseck, P.R. and Pósfai, M. (1999). Airborne minerals and related aerosol particles: Effects on climate and the environment. Proc. Natl. Acad. Sci. U.S.A. 96: 33723379.

Cao, J.J., Wu, F., Chow, J.C., Lee, S.C., Li, Y., Chen, S.W., An, Z.S., Fung, K.K., Watson, J.G., Zhu, C.S. and Liu, S.X. (2005). Characterization and source apportionment of atmospheric organic and elemental carbon during fall and winter of 2003 in Xi'an, China. Atmos. Chem. Phys. 5: 3127-3137.

Cao, J.J., Lee, S.C., Ho, K.F., Fung, K., Chow, J.C. and Watson, J.G. (2006). Characterization of roadside fine particulate carbon and its eight fractions in Hong Kong. Aerosol Air Qual. Res. 6: 106-122.

Castro, L., Pio, C., Harrison, R.M. and Smith, D. (1999). Carbonaceous aerosol in urban and rural European atmospheres: Estimation of secondary organic carbon concentrations. Atmos. Environ. 33: 2771-2781.

Census of India (2011). Government of India. New Delhi.

Chakraborty, A. and Gupta, T. (2010). Chemical characterization and source apportionment of submicron $\left(\mathrm{PM}_{1}\right)$ aerosol in Kanpur region, India. Aerosol Air
Qual. Res. 10: 433-445.

Chatterjee, A., Adak, A., Singh, A.K., Srivastava, M.K., Ghosh, S.K., Tiwari, S., Devara, P.C. and Raha, S. (2010). Aerosol chemistry over a high altitude station at northeastern Himalayas, India. PLoS One 5: 11122.

Chatterjee, A., Dutta, C., Jana, T. and Sen, S. (2012). Fine mode aerosol chemistry over a tropical urban atmosphere: Characterization of ionic and carbonaceous species. $J$. Atmos. Chem. 6: 83-100.

Chow, J.C., Watson, J.G., Pritchett, L.C., Pierson, W. R., Frazier, C.A. and Purcell, R.G. (1993). The DRI thermal/optical reflectance carbon analysis system: Description, evaluation and applications in US air quality studies. Atmos. Environ. 27: 1185-1201.

Chow, J.C., Watson, J.G., Lu, Z., Lowenthal, D.H., Frazier, C.A., Solomon, P.A., Thuillier, R.H. and Magliano, K. (1996). Descriptive analysis of $\mathrm{PM}_{2.5}$ and $\mathrm{PM}_{10}$ at regionally representative locations during SJVAQS/AUSPEX. Atmos. Environ. 30: 2079-2112.

Chow, J.C., Watson, J.G., Kuhns, H., Etyemezian, V., Lowenthal, D.H., Crow, D., Kohl, S.D., Engel Brecht, J.P. and Green, M.C. (2004). Source profiles for industrial, mobile and area sources in the Big Bend Regional Aerosol Visibility and Observational study. Chemosphere 54: 185-208.

Chow, J.C., Watson, J.G., Chen, L.W.A., Chang, M.O., Robinson, N.F., Trimble, D. and Kohl, S. (2007). The IMPROVE A temperature protocol for thermal/optical carbon analysis: Maintaining consistency with a longterm database. J. Air Waste Manage. Assoc. 57: 10141023.

Chow, J.C., Watson, J.G., Robles, J., Wang, X., Chen, L.W.A. Trimble, D.L., Kohl, S.D., Tropp, R.J. and Fung, K.K. (2011). Quality assurance and quality control for thermal/optical analysis of aerosol samples for organic and elemental carbon. Anal. Bioanal. Chem. 401: 31413152.

Das, R., Khezri, B., Srivastava, B., Datta, S., Sikdar, P.K., Webster, R.D. and Wang, X. (2015). Trace element composition of $\mathrm{PM}_{2.5}$ and $\mathrm{PM}_{10}$ from Kolkata-A heavily polluted Indian metropolis. Atmos. Pollut. Res. 6: 742750.

Draxler, R.R. and Hess, G.D. (1998). An overview of the HYSPLIT-4 modeling system for trajectories, dispersion and deposition. Aust. Meteorol. Mag. 47: 295-308.

DRI (2000). Standard operating procedure - thermal/optical reflectance carbon analysis of aerosol filter samples, DRI SOP 2 - 204.6.

Eichel, C., Krämer, M., Schütz, L. and Wurzler, S. (1996). The water-soluble fraction of atmospheric aerosol particles and its influence on cloud microphysics. J. Geophys. Res. 101: 29499-29510.

Ellis, E.C. and Novakov, T. (1982). Application of thermal analysis to the characterization of organic aerosol particles. Sci. Total Environ. 23: 227-238.

Ferek, R.J., Reid, J.S., Hobbs, P.V., Blake, D.R. and Liousse, C. (1998). Emission factors of hydrocarbons, halocarbons, trace gases and particles from biomass burning in Brazil. J. Geophys. Res. 103: 32107-32118. 
Gabriel, R., Mayol-Bracero, O.L. and Andreae, M.O. (2002). Chemical characterization of submicron aerosol particles collected over the Indian Ocean. J. Geophys. Res. 107: INDX2 4-1-INDX2 4-12.

Gawhane, R.D., Rao, P.S.P., Budhavant, K.B., Waghmare, V., Meshram, D.C. and Safai, P.D. (2017). Seasonal variation of chemical composition and source apportionment of $\mathrm{PM}_{2.5}$ in Pune, India. Environ. Sci. Pollut. Res. 24: 21065-21072.

George, S.K. and Nair, P.R. (2008). Aerosol mass loading over the marine environment of Arabian Sea during ICARB: Sea-salt and non-sea-salt components. J. Earth Syst. Sci. 117: 333-344.

Granat, L. (1972). On the relation between $\mathrm{pH}$ and the chemical composition in atmospheric precipitation. Tellus 24: 550-560.

Gu, J., Bai, Z., Liu, A., Wu, L., Xie, Y., Li, W., Dong, H. and Zhang, X. (2010). Characterization of atmospheric organic carbon and element carbon of $\mathrm{PM}_{2.5}$ and $\mathrm{PM}_{10}$ at Tianjin, China. Aerosol Air Qual. Res. 10: 167-176.

Guidry, M.W. and Mackenzie, F.T. (2000). Apatite weathering and the Phanerozoic phosphorus cycle. Geology 28: 631-634.

Hegde, P., Sudheer, A.K., Sarin, M.M. and Manjunatha, B.R. (2007). Chemical characteristics of atmospheric aerosols over southwest coast of India. Atmos. Environ. 41: 7751-7766

Hertel, O., Skjøth, C.A., Reis, S., Bleeker, A., Harrison, R.M., Cape, J.N., Fowler, D., Skiba, U., Simpson, D., Jickells, T. and Kulmala, M. (2012). Governing processes for reactive nitrogen compounds in the European atmosphere. Biogeosciences 9: 4921-4954.

Hitchcock, D.R., Spiller, L.L. and Wilson, W.E. (1980). Sulfuric acid aerosols and $\mathrm{HCl}$ release in coastal atmospheres: Evidence of rapid formation of sulfuric acid particulates. Atmos. Environ. 14: 165-182.

Ho, K., Lee, S., Chow, J.C. and Watson, J.G. (2003). Characterization of $\mathrm{PM}_{10}$ and $\mathrm{PM}_{2.5}$ source profiles for fugitive dust in Hong Kong. Atmos. Environ. 37: 10231032.

Holland, H.D. (1984). The chemical evolution of the atmosphere and oceans. Princeton University Press, USA.

IPCC (2013). Climate change 2013: The physical science basis. contribution of working group I to the fifth assessment report of the intergovernmental panel on climate change. Stocker, T.F., D. Qin, G.K. Plattner, M. Tignor, S.K. Allen, J. Boschung, A. Nauels, Y. Xia, V. Bex and P.M. Midgley (Eds.), Cambridge University Press, Cambridge, United Kingdom and New York, NY, USA.

Jaenicke, R. (1981). Atmospheric aerosols and global climate, In Climatic variations and variability: Facts and theories. Berger, A. (Ed.), Springer Netherlands, Dordrecht, pp. 577-597.

Jaenicke, R. (1984). Our knowledge about the atmospheric aerosol. International Commission for Cloud Physics $1^{\text {th }}$ Int. Conf. on Atmospheric Aerosols, Condensation and Ice Nuclei, (Vol. 1).
Jain, S., Sharma, S.K., Choudhary, N., Masiwal, R., Saxena, M., Sharma, A., Mandal, T.K., Gupta, A., Gupta, N.C. and Sharma, C. (2017). Chemical characteristics and source apportionment of $\mathrm{PM}_{2.5}$ using PCA/APCS, UNMIX and PMF at an urban site of Delhi, India. Environ. Sci. Pollut. Res. 24: 14637-14656.

Jaiprakash, A., Singhai, Habib, G., Raman, R.S. and Gupta, T. (2017). Chemical characterization of $\mathrm{PM}_{1.0}$ aerosol in Delhi and source apportionment using positive matrix factorization. Environ. Sci. Pollut. Res. 24: 445-462.

John, W., Hering, S., Reischl, G., Sasaki, G. and Goren, S. (1983). Characteristics of Nuclepore filters with large pore size-II. Filtration properties. Atmos. Environ. 17: 373-382.

Kaneyasu, N., Ohta, S. and Murao, N. (1995). Seasonal variation in the chemical composition of atmospheric aerosols and gaseous species in Sapporo, Japan. Atmos. Environ. 29: 1559-1568.

Keene, W.C., Pszenny, A.A., Galloway, J.N. and Hawley, M.E. (1986). Sea-salt corrections and interpretation of constituent ratios in marine precipitation. J. Geophys. Res. 91: 6647-6658.

Kelly, K.E., Kotchenruther, R., Kuprov, R. and Silcox, G.D. (2013). Receptor model source attributions for Utah's Salt Lake City air shed and the impacts of wintertime secondary ammonium nitrate and ammonium chloride aerosol. J Air Waste Manage. Assoc. 63: 575590.

Kim, E. and Hopke, P.K. (2004). Improving source identification of fine particles in a rural north-eastern US area utilizing temperature-resolved carbon fractions. J. Geophys. Res. 109: D09204.

Kim, Y.P., Moon, K.C., Lee, J.H. and Baik, N.J. (1999). Concentrations of carbonaceous species in particles at Seoul and Cheju in Korea. Atmos. Environ. 33: 27512758.

Knipping, E.M. and Dabdub, D. (2003). Impact of chlorine emissions from sea-salt aerosol on coastal urban ozone. Environ. Sci. Technol. 37: 275-284.

Kumar, D.B. and Verma, S. (2016). Potential emission flux to aerosol pollutants over Bengal Gangetic plain through combined trajectory clustering and aerosol source fields analysis. Atmos. Res. 178: 415-425.

Lee, C.T., Ram, S.S., Nguyen, D.L., Chou, C.C., Chang, S.Y., Lin, N.H., Chang, S.C., Hsiao, T.C., Sheu, G.R., Ou-Yang, C.F. and Chi, K.H. (2016). Aerosol chemical profile of near-source biomass burning smoke in Sonla, Vietnam during 7-SEAS campaigns in 2012 and 2013. Aerosol Air Qual. Res. 16: 2603-2617.

Li, W. and Shao, L. (2009). Observation of nitrate coatings on atmospheric mineral dust particles. Atmos. Chem. Phys. 9: 1863-1871.

Lohmann, U. and Feichter, J. (2005). Global indirect aerosol effects: A review. Atmos. Chem. Phys. 5: 715737.

Malaguti, A., Mircea, M., La Torretta, T.M., Telloli, C., Petralia, E., Stracquadanio, M. and Berico, M. (2015). Chemical composition of fine and coarse aerosol particles 
in the Central Mediterranean area during dust and nondust conditions. Aerosol Air Qual. Res. 15: 410-425.

Matsumoto, K. and Tanaka, H. (1996). Formation and dissociation of atmospheric particulate nitrate and chloride: An approach based on phase equilibrium. Atmos. Environ. 30: 639-648.

Mayol-Bracero, O.L., Gabriel, R., Andreae, M.O., Kirchstetter, T., Novakov, T., Ogren, J., Sheridan, P. and Streets, D. (2002). Carbonaceous aerosols over the Indian Ocean during INDOEX: Chemical characterisation, optical properties and probable sources. J. Geophys. Res. 107: INX2 29-1-INX2 29-21.

McDow, S.R. and Huntzicker, J.J. (1990). Vapor adsorption artifact in the sampling of organic aerosol: Face velocity effects. Atmos. Environ. 24: 2563-2571.

Millero, F.J. and Sohn, M.L. (1992). Composition of the major components of seawater. Chemical Oceanography. CRC Press Inc. United Stated of America, pp. 59-113.

Morales, J.A., Pirela, D., de Nava, M.G., de Borrego, B.S., Velásquez, H. and Durán, J. (1998). Inorganic watersoluble ions in atmospheric particles over Maracaibo Lake Basin in the western region of Venezuela. Atmos. Res. 46: 307-320.

Olivier, J.G.J., Bouwman A.F., Van der Hoek, K.W. and Berdowski, J.J.M. (1998). Global air emission inventories for anthropogenic sources of $\mathrm{NO}_{\mathrm{x}}, \mathrm{NH}_{3}$ and $\mathrm{N}_{2} \mathrm{O}$ in 1990. Environ. Pollut. 102: 135-148.

Panda, S., Sharma, S.K., Mahapatra, P.S., Panda, U., Rath, S., Mahapatra, M., Mandal, T.K. and Das, T. (2016). Organic and elemental carbon variation in $\mathrm{PM}_{2.5}$ over megacity Delhi and Bhubaneswar, a semi-urban coastal site in India. Nat. Hazards 80: 1709-1728.

Pandolfi, M., Cusack, M., Alastuey, A. and Querol, X. (2011). Variability of aerosol optical properties in the Western Mediterranean Basin. Atmos. Chem. Phys. 11: 8189-8203.

Pani, S.K. and Verma, S. (2014). Variability of winter and summertime aerosols over eastern India urban environment. Atmos. Res. 137: 112-124.

Park, S.S. and Cho, S.Y. (2011). Tracking sources and behaviors of water-soluble organic carbon in fine particulate matter measured at an urban site in Korea. Atmos. Environ. 45: 60-72.

Patil, R.S., Kumar, R., Menon, R., Shah, M.K. and Sethi, V. (2013). Development of particulate matter speciation profiles for major sources in six cities in India. Atmos. Res. 132: 1-11.

Perrino, C., Canepari, S. and Catrambone, M. (2013). Comparing the performance of Teflon and quartz membrane filters collecting atmospheric PM: Influence of atmospheric water. Aerosol Air Qual. Res. 13: 137147.

Perrino, C., Canepari, S., Catrambone, M., Dalla Torre, S., Rantica, E. and Sargolini, T. (2009). Influence of natural events on the concentration and composition of atmospheric particulate matter. Atmos. Environ. 43: 4766-4779.

Pipal, A.S., Tiwari, S. and Satsangi, P.G. (2016). Seasonal chemical characteristics of atmospheric aerosol particles and its light extinction coefficients over Pune, India. Aerosol Air Qual. Res. 16: 1805-1819.

Poschl, U. (2005). Atmospheric aerosols: Composition, transformation, climate and health effects. Angew. Chem. Int. Ed. 44: 7520-7540.

Poulain, L., Spindler, G., Birmili, W., Plass-Dülmer, C., Wiedensohler, A. and Herrmann, H. (2011). Seasonal and diurnal variations of particulate nitrate and organic matter at the IfT research station Melpitz. Atmos. Chem. Phys. 11: 12579-12599.

Priyadharshini, B., Verma, S., Giles, D.M. and Holben, B.N. (2018). Discerning the pre-monsoon urban atmosphere aerosol characteristic and its potential source type remotely sensed by AERONET over the Bengal Gangetic plain. Environ. Sci. Pollut. Res. Int. 25: 22163-22179.

Rai, P., Chakraborty, A., Mandariya, A.K. and Gupta, T. (2016). Composition and source apportionment of $\mathrm{PM}_{1}$ at urban site Kanpur in India using PMF coupled with CBPF. Atmos. Res. 178: 506-520.

Rajput, P., Singh, D.K., Singh, A.K. and Gupta, T. (2018). Chemical composition and source-apportionment of sub-micron particles during wintertime over Northern India: New insights on influence of fog-processing. Environ. Pollut. 233: 81-91.

Ram, K., Sarin, M. and Hegde, P. (2008). Atmospheric abundances of primary and secondary carbonaceous species at two high-altitude sites in India: Sources and temporal variability. Atmos. Environ. 42: 6785-6796.

Ram, K. and Sarin, M.M. (2010). Spatio-temporal variability in atmospheric abundances of EC, OC and WSOC over Northern India. J Aerosol Sci. 41: 88-98.

Ram, K., Sarin, M. and Hegde, P. (2010). Long-term record of aerosol optical properties and chemical composition from a high-altitude site (Manora Peak) in Central Himalaya. Atmos. Chem. Phys. 10: 11791-11803.

Ram, K., Sarin, M.M. and Tripathi, S.N. (2010a). A 1 year record of carbonaceous aerosols from an urban site in the Indo-Gangetic Plain: Characterization, sources, and temporal variability. J. Geophys. Res. 115: D24313.

Ram, K., Sarin, M.M., Sudheer, A.K. and Rengarajan, R. (2012). Carbonaceous and secondary inorganic aerosols during wintertime fog and haze over urban sites in the Indo-Gangetic Plain. Aerosol Air Qual. Res. 12: 359370.

Ram, K., Singh, S., Sarin, M.M., Srivastava, A.K. and Tripathi, S.N. (2016). Variability in aerosol optical properties over an urban site, Kanpur, in the IndoGangetic Plain: A case study of haze and dust events. Atmos. Res. 174: 52-61.

Rastogi, N. and Sarin, M. (2009). Quantitative chemical composition and characteristics of aerosols over western India: One-year record of temporal variability. Atmos. Environ. 43: 3481-3488.

Rastogi, N., Patel, A., Singh, A. and Singh, D. (2015). Diurnal variability in secondary organic aerosol formation over the Indo-Gangetic Plain during winter using online measurement of water-soluble organic carbon. Aerosol Air Qual. Res. 15: 2225-2231.

Rastogi, N., Singh, A., Singh, D. and Sarin, M.M. (2014). 
Chemical characteristics of $\mathrm{PM}_{2.5}$ at a source region of biomass burning emissions: Evidence for secondary aerosol formation. Environ. Pollut. 184: 563-569.

Rau, J.A. (1986). Residential wood combustion aerosol characterization as a function of size and source spportionment using chemical mass balance modeling (Ph.D. Dissertation). Oregon Graduate Center, Beaverton, OR, USA.

Reid, J., Koppmann, R., Eck, T. and Eleuterio, D. (2005). A review of biomass burning emissions part II: Intensive physical properties of biomass burning particles. Atmos. Chem. Phys. 5: 799-825.

Rengarajan, R., Sarin, M. and Sudheer, A. (2007). Carbonaceous and inorganic species in atmospheric aerosols during wintertime over urban and high-altitude sites in North India. J. Geophys. Res. 112: D21307.

Rosenfeld, D., Lohmann, U., Raga, G.B., O'Dowd, C.D., Kulmala, M., Fuzzi, S., Reissell, A. and Andreae, M.O. (2008). Flood or drought: How do aerosols affect precipitation? Science 321: 1309-1313.

Roy, A., Chatterjee, A., Tiwari, S., Sarkar, C., Das, S.K., Ghosh, S.K. and Raha, S. (2016). Precipitation chemistry over urban, rural and high altitude Himalayan stations in eastern India. Atmos. Res. 181: 44-53.

Ruellan, S., Cachier, H., Gaudichet, A., Masclet, P. and Lacaux, J.P. (1999). Airborne aerosols over central Africa during the Experiment for Regional Sources and Sinks of Oxidants (EXPRESSO). J. Geophys. Res. 104: 30673-30690.

Safai, P., Raju, M., Rao, P. and Pandithurai, G. (2014). Characterization of carbonaceous aerosols over the urban tropical location and a new approach to evaluate their climatic importance. Atmos. Environ. 92: 493-500.

Sahu, L., Sheel, V., Pandey, K., Yadav, R., Saxena, P. and Gunthe, S. (2015). Regional biomass burning trends in India: Analysis of satellite fire data. J. Earth Syst. Sci. 124: 1377-1387.

Satsangi, P.G. and Yadav, S. (2014). Characterization of $\mathrm{PM}_{2.5}$ by $\mathrm{X}$-ray diffraction and scanning electron microscopy-energy dispersive spectrometer: Its relation with different pollution sources. Int. J. Environ. Sci. Technol. 11: 217-232.

Seinfeld, J.H. and Pandis, S.N. (1998). Atmospheric chemistry and physics: From air pollution to climate change. 2nd Edn. Wiley Interscience, New York.

Seinfeld, J.H. and Pandis, S.N. (2012). Atmospheric chemistry and physics: From air pollution to climate change. 2nd Edn. John Wiley \& Sons, New York.

Sharma, M., Kishore, S., Tripathi, S.N. and Behera, S.N. (2007). Role of atmospheric ammonia in the formation of inorganic secondary particulate matter: A study at Kanpur, India. J. Atmos. Chem. 58: 1-17.

Singh, A., Rastogi, N., Patel, A., Satish, R.V. and Singh, D. (2016). Size-segregated characteristics of carbonaceous aerosols over the Northwestern Indo-Gangetic Plain: Year round temporal behavior. Aerosol Air Qual. Res. 16: $1615-1624$.

Sinha, P., Kaskaoutis, D., Manchanda, R. and Sreenivasan, S. (2012). Characteristics of aerosols over Hyderabad in southern Peninsular India: Synergy in the classification techniques. Ann. Geophys. 30: 1393-1410.

Solomon, P.A., Fall, T., Salmon, L., Cass, G.R., Gray, H.A. and Davidson, A. (1989). Chemical characteristics of $\mathrm{PM}_{10}$ aerosols collected in the Los Angeles area. JAPCA 39: 154-163.

Squizzato, S., Masiol, M., Agostini, C., Visin, F., Formenton, G., Harrison, R.M. and Rampazzo, G. (2016). Factors, origin and sources affecting $\mathrm{PM}_{1}$ concentrations and composition at an urban background site. Atmos. Res. 180: 262-273.

Srivastava, A., Gupta, S. and Jain, V. (2009). Winter-time size distribution and source apportionment of total suspended particulate matter and associated metals in Delhi. Atmos. Res. 92: 88-99.

Sudheer, A.K., Rengarajan, R., Deka, D., Bhushan, R., Singh, S.K. and Aslam, M.Y. (2014). Diurnal and seasonal characteristics of aerosol ionic constituents over an urban location in western India: Secondary aerosol formation and meteorological influence. Aerosol Air Qual. Res. 14: 1701-1713.

Tiwari, S., Srivastava, A., Bisht, D., Safai, P. and Parmita, P. (2013). Assessment of carbonaceous aerosol over Delhi in the Indo-Gangetic Basin: Characterization, sources and temporal variability. Nat. Hazards 65: 1745-1764.

Turpin, B.J. and Lim, H.J. (2001). Species contributions to $\mathrm{PM}_{2.5}$ mass concentrations: Revisiting common assumptions for estimating organic mass. Aerosol Sci. Technol. 35: 602-610.

Vecchi, R., Valli, G., Fermo, P., D’Alessandro, A., Piazzalunga, A. and Bernardoni, V. (2009). Organic and inorganic sampling artifacts assessment. Atmos. Environ. 43: 1713-1720.

Venkataraman, C., Reddy, C.K., Josson, S. and Reddy, M.S. (2002). Aerosol size and chemical characteristics at Mumbai, India, during the INDOEX-IFP (1999). Atmos. Environ. 36: 1979-1991.

Venkataraman, C., Habib, G., Kadamba, D., Shrivastava, M., Leon, J.F., Crouzille, B., Boucher, O. and Streets, D. (2006). Emissions from open biomass burning in India: Integrating the inventory approach with high-resolution Moderate Resolution Imaging Spectroradiometer (MODIS) active-fire and land cover data. Global Biogeochem. Cycles 20: GB2013.

Verma, S., Pani, S.K. and Bhanja, S.N. (2013). Sources and radiative effects of wintertime black carbon aerosols in an urban atmosphere in east India. Chemosphere 90: 260-269.

Verma, S., Reddy, D.M., Ghosh, S., Kumar, D.B. and Chowdhury, A.K. (2017). Estimates of spatially and temporally resolved constrained black carbon emission over the Indian region using a strategic integrated modelling approach. Atmos. Res. 195: 9-19.

Vinoj, V., Rasch, P.J., Wang, H., Yoon, J.H., Ma, P.L., Landu, K. and Singh, B. (2014). Short-term modulation of Indian summer monsoon rainfall by West Asian dust. Nat. Geosci. 7: 308-313.

Virkkula, A., Teinilä, K., Hillamo, R., Kerminen, V.M., Saarikoski, S., Aurela, M., Viidanoja, J., Paatero, J., 
Koponen, I. and Kulmala, M. (2006). Chemical composition of boundary layer aerosol over the Atlantic Ocean and at an Antarctic site. Atmos. Chem. Phys. 6: 3407-3421.

Ward, J.H. (1963). Hierarchical grouping to optimize an objective function. J. Am. Stat. Assoc. 58: 236-244.

White, W.H. (2008). Chemical markers for sea salt in IMPROVE aerosol data. Atmos. Environ. 42: 261-274.

Zhang, Y., Wu, S.Y., Hu, J., Krishnan, S., Wang, K., Queen, A., Aneja, V.P. and Arya, P. (2008). Modeling agricultural air quality: Current status, major challenges, and outlook. Atmos. Environ. 42: 3218-3237.
Zhang, Y., Tang, L., Croteau, P. L., Favez, O., Sun, Y., Canagaratna, M. R., Wang, Z., Couvidat, F., Albinet, A., Zhang, H. and Sciare, J. (2017). Field characterization of the $\mathrm{PM}_{2.5}$ aerosol chemical speciation monitor: Insights into the composition, sources, and processes of fine particles in eastern China. Atmos. Chem. Phys. 17: 14501-14517.

Received for review, January 19, 2018 Revised, July 20, 2018 Accepted, October 6, 2018 